\title{
Müellifleri Tarafından Tamamlanamamış Tefsirler
}

\author{
Exegeses not Completed by Their Authors
}

\author{
Hidayet Aydar ${ }^{*} \odot$
}

\section{Öz}

Tefsir tarihi incelendiğinde eksik kalmış tefsirlerin mevcudiyeti müşahede edilmektedir. Bu tefsirler müelliflerinin vefat nedeniyle eksik kalmışlardır. Başka işlerle meşguliyet, zamanı iyi kullanmama gibi hususlar da bazı tefsirlerin eksik kalmasında etkili olmuştur. Söz konusu eksik tefsirlerden bir kısmı daha sonraki dönemlerde başkaları tarafindan tamamlanmıştır, ancak bir kısmı hâlen eksik kalmış durumdadır. Bu çalışmada eksik kalan veya sonradan tamamlanan tefsirler ve müellifleri hakkında bazı bilgiler verilmektedir. Aynı zamanda mezkûr tefsirler arasından sonradan bir şekilde tamamlananlar ve bunların ikmâl edilmesinde görevli olanlar hakkında bilgi sunulmaktadır. Onların bu görevi nasıl ve neden yaptıkları, nasıl bir katkı sağladıkları üzerinde de durulmaktadır. Tefsir tarihi içerisinde muhtelif coğrafyalarda müellifleri tarafindan tamamlanmamış çok sayıda tefsir bulunmaktadır. Bunlar arasında Arapça dışındaki dillerde yazılıp tamamlanmamış tefsirler de bulunmaktadır. Ayrıca Sünni ve Şiî anlayış esas alınarak yazılıp eksik kalmış tefsirlerin yanı sıra daha küçük ve dar alanda etkili mezheplere göre yazılıp tamamlanamamış tefsirleri görmek de mümkündür. Eksik tefsirlerin ilk örneklerine hicrî 3. asırdan itibaren şahit olunabilmektedir. 20 ve 21. yüzyılda yazılıp tamamlanamamış tefsirler de mevcuttur. Çalışmada bütün bu nitelikleri ihtiva eden eserler hakkında değerlendirmeler yapılmaktadır. Bu minvalde çalışmada zikri geçen tefsirler, müelliflerinin vefat tarihlerine göre kronolojik olarak sunulmaktadır.

\section{Anahtar Kelimeler}

Tefsir, müellif, nâtamam, vefat, ikmâl

\begin{abstract}
When the History of Tafsir (exegesis) is analyzed, incomplete exegeses are observed. The writing of these exegeses is incomplete because of the death of their authors. Notably, there may be other reasons why exegeses are incomplete. In the subsequent periods, some of these exegeses were completed. This study provides information on these incomplete exegeses and their authors. If the exegeses were completed in some manner later, the individuals who have partaken in this work and why and how they performed it are also emphasized. Many exegeses in the History of Tafsir were completed by their authors, namely, those in every geography. Incomplete exegeses written in languages other than Arabic have also been observed. In addition to the incomplete exegeses written based on Sunni and Shiite understandings, there are incomplete exegeses written based on understanding of the sects that are influential in a smaller, narrower area. The first examples of incomplete exegeses are from the third Hijri century. There are also exegeses that have been written but could not have been completed recently. In this study, determinations are made according to all these qualifications. Once again, the exegeses mentioned in the study are presented chronologically according to the death dates of their authors.
\end{abstract}

\section{Keywords}

Exegesis, author, death, incomplete, completion

\footnotetext{
* Sorumlu Yazar: Hidayet Aydar (Prof. Dr.), İstanbul Üniversitesi, Ilahiyat Fakültesi, Tefsir Ana Bilim Dalı, İstanbul, Türkiye.

E-posta: hidayet@istanbul.edu.tr ORCID: 0000-0002-7563-5073

Atff: Hidayet Aydar, "Müellifleri Tarafindan Tamamlanamamış Tefsirler." darulfunun ilahiyat 32, 1 (2021): 117-145. https://doi.org/10.26650/di.2021.32.1.839107
} 


\section{Extended Summary}

Qur'an was revealed to be understood by individuals and practiced. For this reason, many tafseers have been written since $2^{\text {nd }}$ century Hijri. Some of these tafseers were completed by their mofassirs and later copied and printed many times for the use of the general public. Although there are hundreds of complete tafseers, many tafseers were intended to be finished by their mofassirs but were incomplete because of reasons such as the death of mofassir, negligence, or insufficient time. For some other mofassirs, they could not complete their tafseers because they were jailed and not allowed to write.

Those incomplete tafseers were not only detected in the Arabic language and in the Arabian peninsula but in various languages and geographies such as Turkish, Persian, and Urdu and Anatolia, Iran, and the Indian subcontinent, respectively. First, examples of incomplete tafseers can be found from $3^{\text {rd }}$ century Hijri, but there are many incomplete tafseers from the $20^{\text {th }}$ and $21^{\text {st }}$ centuries. Some of these tafseers were completed later, but most remain incomplete.

Incomplete tafseers can be defined as those tafseers for which the original mofassir intended to tafseer the whole Qur'an but did not. For this reason, ahkam tafseers (tafseers related to ruling), Sufi tafseers, tafseers focusing on linguistics, and tafseers that were complete before but have since lost parts were not examined in this study. Additionally, tafseers that are still being written today but that have only some parts published were also not included because their mofassirs might complete them. Incomplete tafseers not in these categories were detected, analyzed, and listed chronologically according to the date of death of mofassirs.

The first tafseer we analyze is Bahr al-hakâik va al-meânî fî tafseer al-seb' al-methânî, written by Najmuddin Daye, who lived in Iran and Anatolia. This tafsir was later completed by Alauddevle al-Simnânî. Another important incomplete tafseer is Bahr al-ulûm, by Alauddin Ali al-Semerqandî, who lived in Central Asia and Anatolia. Bahr al-ulûm was later completed by Esam Karamanî. Tafseer al-Jalâleyn, by Jalâledin Mahalli, an Egyptian scholar, is also examined in this study. This important tafseer was later completed by his student Jalaleddin Suyûti. Ibn Kemal Pasha is one of the most important Ottoman Shayk al-Islam. He attempted to write a comprehensive, voluminous tafseer, but after finishing surah as-Saffat, he became ill and died; thus, his tafseer is incomplete. Another incomplete tafseer is Tarjumân al-Kur'ân, written by Siddiq Hasan Khan, a famous mofassir raised on the Indian subcontinent. Siddiq Hasan Khan, married to Shah Jahan Begum, had responsibilities in government administration. He subsequently experienced substantial pressure and problems in his political and family life and died at a young age. Upon his death, his other works and his tafseer were incomplete. Tafseer al-Kur'ân al-Hakîm, also known as Tefseer al-Menâr, is another important incomplete tafseer. This tafseer was being written by Egyptian scholar Muhammed Abduh until the $124^{\text {th }}$ ayat of 
surah al-Nisa and was incomplete upon his death. Later, Abduh's student Muhammed Reshid Rida attempted to complete the tafsir after the ayat $125^{\text {th }}$ of surah al-Nisa. Reshid Riza wrote until the 52 $2^{\text {nd }}$ ayat of surah Yusuf, 30 years between 1905 and 1935, until his death. This incomplete tafseer was published in 12 volumes. Adwâ al-bayân fî îdâh al-Kur'âni bi al-Kur'ân is another incomplete tafseer written by Muhammed al-Emin alShinqîtî, who is originally from Mauritania but worked in Saudi Arabia. This incomplete tafseer later was continued by Atiyye Muhammed b. Sâlim after his teacher Shinqiti's death, starting from surah al-Mujadala, which is where Shinqiti ended his work. Another incomplete tafseer is that of Iranian scholar Muhammed Husain Tabatabâî, titled Tefseer al-bayân fî al-muvâfaqa beyne al-hadîth wa al-Kur'ân. When the mofassir died, he had written until the $56^{\text {th }}$ ayat of surah Yusuf. Subsequently, this was published without the rest of the Qur'an. Many other incomplete tafseers are examined further in this study. 


\section{Giriş}

Tefsir tarihinde farklı niteliklere sahip, muhtelif konumları ve durumları olan çok sayıda tefsir vardır. Tefsirlerden bazıları çok ciltli, çok hacimli iken, bazıları daha az hacimli ve cilt sayısı daha az olabilmektedir. Bazıları rivayet ağırlıklı iken, dirayet yönü ağı basan, işârî nitelikte olan, yalnızca ahkâm ayetlerini işleyen, gramatik tahlillerle yetinen tefsirler de mevcuttur. Bazı tefsirler müellifine, ithaf edildiği sultan veya yönetici tarafından mükâfat olarak verilen kese kese altın kazandırmış, bazıları ise müellifi için külfet ve zahmet olmaktan öteye geçememiştir. Bazı tefsirler sultanın emir ve iradesiyle yazılmışken, bazı tefsirler de sultan tarafından yasaklanmıştır. Okuyanın imanını kuvvetlendireceği ve büyük sevap kazandıracağı söylenerek okunması teşvik edilen tefsirler olduğu gibi okunmasının imanı zedeleyeceği, kişiyi şek ve şüpheye düşüreceği, bu yüzden de okunmasının sakıncalı olduğu söylenen tefsirler de vardır. Bazı tefsirler, yalnızca müellifi tarafından yazılmış, bazıları ise, müellifine birçok öğrencisinin yardımıyla telif edilmiştir. Bazı tefsirler, müellifin -kendi iddiasına göre- rüyasında aldığ bir işaretle yazılmaya başlanmışlardır, hatta yazım esnasında bile müellifleri yine kendi iddialarına göre ilhama mazhar olmuştur. Böylece eser madde ve mana dünyasının ortak eseri olarak, büyük zahmetler çekilmeden zuhur etmiştir. Bazıları ise müellifin daha önceden tasarlaması, planlaması ve buna göre araştırmalar yapması ile yani büyük bir emeğin eseri olarak ortaya çıkmışlardır. Zindanda yahut hapishanenin soğuk odalarında veya esir kamplarında en zor şartlar altında yazılmış olan tefsirlerin yanı sıra, sırça saraylar kadar güzel ve rahat ortamlarda telif edilmiş olanlar da vardır. Yazıldıktan sonra özenle saklanan, büyük bir miras gibi korunan tefsirlere mukabil hiç itibar görmeyen, kendi haline terkedilen tefsirler de mevcuttur. Yazıldıktan sonra defalarca istinsah edilen, tabedilen tefsirler olduğu gibi hâlâ kütüphanelerin tozlu ve küflü raflarında beklemekte olanlar da vardır. Bazı tefsirler mahir hattatların en güzel hatlarıyla ince bir nakış gibi kâğıda işlenmiş, mühezzipler tarafından sayfaları en güzel şekilde süslenmiş ve en pahalı deri ciltlerle ciltlenmişken, bazıları da hâlâ müsvedde halinde durmaktadır. Bazı tefsirler yazıldıktan sonra büyük kalabalıkların ilgisine mazhar olmuş, böylece mevcudiyetini korumuşken, bazı tefsirler de yazıldıktan kısa bir süre sonra çıkan yangında yanmış, sele kapılmış ya da eşkıya tarafından el konulup parçalanmıştır. Bütün bunlar tek bir nüshadan ibaret oldukları için yok olup gitmişlerdir. Bazı tefsirler büyük kalabalıklar tarafindan sahiplenilmiş, bazıları ise yine büyük kalabalıklar tarafından yok edilmiştir. Bazı tefsirleri, müellifi her satırını abdestli olarak yazmışken, bazılarını, müellifinin abdestsiz hatta cünüp olarak yazdığı iddia edilmiştir. Tefsirlerin genellikle kişiyi iman ve ibadet konusunda daha hassas kılmaya, daha çok mütedeyyin bir kişi haline getirmeye çalışmalarına rağmen, kişiyi imanî konularda şüpheye düşüren ilhâdî 
tefsirler de bulunmaktadır. Kim tarafından yazıldığı kesin olarak bilinmeyen veya başka saiklerle müellifi tarafından yazılıp daha sonra başka bir âlime isnad edilen müellifi meçhul tefsirler de mevcuttur. Bazı tefsirler ise müellifi tarafindan tamamlanmışken, bazıları eksik kalmıştır. Eksik tefsirlerin bir kısmı hâlâ eksik olarak duruyorken, bazıları daha sonra tamamlanmışlardır.

$\mathrm{Bu}$ araştırmada eksik kalmış tefsirler üzerinde durulmaktadır. Bu tefsirlerin bazılarını bir müellif telif etmiş, ama bir süre sonra ya vefat ettiği için, ya büyük meşguliyetleri olduğundan yahut imkânsızlıklar yüzünden ya da başka bir sebepten tefsir eksik kalmıştır. Ancak bu tefsirler arasında daha sonra gelen âlimlerin tamamlamış oldukları eserler de bulunmaktadır.

Bu çalışmada mahiyeti itibariyle eksik olan tefsirler kapsam dişında tutulmuştur. Bu cümleden olarak İbn Abbas, İbn Mes'ûd, Hz. Aişe gibi bazı sahabilere nispet edilen eksik tefsirler ile Mücahid, Dahhâk, Katâde gibi tâbiûn âlimlerine ait noksan tefsirlere yer verilmemiştir. İbn Cüreyc, el-Kisâî gibi tebe-i tâbiîn halkasından olan âlimlere ait tefsirler üzerinde durulmadığı gibi daha sonraki dönem âlimlerinden olan Abdurrezzak b. Hemmâm, Hud b. Muhakkam el-Huvvârî gibi zevata nispet edilerek tab edilmiş olan tefsirler de burada mevzu bahis edilmemiştir. Zira bunlar, kâmil bir tefsir olarak başlanıp müellifi sonradan vefat ettiği veya yazmaktan vazgeçtiği için yahut başka bir nedenle eksik bırakılan eserler değildir. Yine burada Tahavî, Cessâs, İlkiyâ el-Herrâsî, Ebubekir İbnu'l-Arabî gibi âlimlerin ahkâmu'l-Kur'ân türünden; Sehl b. Abdillah Tüsteri, Ebû Abdirrhaman Sülemî gibi âlimlerin işâ̂î/tasavvufî türden; Buhârî, Müslim, Tirmizî, Nesâî gibi âlimlerin hadis mecmuaları içinde yer alan hadis derlemesi türünden; Ferra, Ebû Ubeyde Ma'mer b. el-Müsennâ, Ahfeş, İbn Kuteybe, Zeccâc, Nehhâs gibi âlimlerin lügavî türden veya daha sonraki dönemlerde Tantâvî Cevherî gibi zevatın yazdıkları ilmî türden tefsirler olması hasebiyle Kur'ân'ın tamamını değil, sadece ilgili kısımları ele alan tefsirler de kapsam dışı tutulmaktadır. Zira bunlar da müellifi tarafından eksik bırakılmış eserler değildir, bunların yapısı bunu gerektiği için böyle yapılmışlardır ve bu yönüyle bunlar eksik değil, tam tefsirlerdir. O yüzden bunların üzerinde durulmamaktadır. Yine burada el-Muntehab gibi bir komisyon veya iki müellif tarafından oluşturulup, her birinin belli bir kısmını yazdığı eserler de zikredilmemektedir. Çünkü bunlar da bir kişi tarafından tamamlanmak üzere yazılan fakat herhangi bir sebepten dolayı eksik kalmış eserler kategorisinde değillerdir. Çalışmada Süfyanu's-Sevrî gibi bazı zevatın tefsirinde olduğu üzere Kur'ân'ın çok büyük bir kısmını tefsir ettiği halde kısa sûrelerin eksik kaldığ1 tefsirler de ele alınmamaktadır. Burada Ebûbekir el-Esam, Ebû Ali el-Cübbâî, Ebu'l-Kasım el-Belhî, Ebû Muslim el-Isfehânî vb. âlimlerin tefsirleri gibi bugün elimizde eksik olarak bulunan tefsirlere de yer verilmemektedir. Çünkü bu tefsirler 
zamanında müellifleri tarafından tamamlanmış olmasına rağmen, tarih içerisinde tamamı veya bazı kısımları kaybolmuştur. O yüzden bunlar üzerinde durduğumuz kategoriye girmemektedirler. Burada Aişe Abdurrahman bintu'ş-Şâti' örneğinde olduğu gibi müellifi tarafından birkaç sûre tefsiri mahiyetinde hazırlanmış eserler de ele alınmamaktadır. Çünkü bunlar Kur'ân'ın tamamını tefsir etmek niyetiyle yapılıp da ölüm veya benzer bir nedenle eksik kalmış tefsirler değildir. Yine burada İbn Teymiyye, İbn Kayyım el-Cevziyye gibi bazı âlimlerin muhtelif eserlerinden derlenerek bunların adına neşredilen tefsirler de mevzu bahis edilmemektedir. Çünkü bunlar da tam bir Kur'ân tefsiri olsun diye yazılmamışlardır. Burada Ruhu'l-Furkan, Ilahi Hitabın Tefsiri örneklerinde olduğu gibi eksik olmakla birlikte yazımı devam eden veya henüz müellifleri hayatta olup yazımı süren eserler de kapsam dışı bırakılmıştır. Bugün eksik olan eserin, önümüzdeki dönemlerde müellif tarafindan tamamlanma durumu söz konusudur. Bu kategorilerin dişında tespit edebildiğimiz tefsirler çalışmanın temelini oluşturmakta ve bunlar üzerinde durulmaktadir.

$\mathrm{Bu}$ çalışma tamamlanmamış tefsirlerin ortaya koyulması amacıyla oluşturulmuştur. Bunun için müfessirlerin hayatını işleyen çok sayıda tabakât ve terâcim türü eser gözden geçirilmiştir. Ayrıca müfessirleri ve tefsirlerini ele alan müstakil kitap, tez, makale, tebliğ ve ansiklopedi maddesi gibi çalışmalar da elden geçirilmiştir. Yaptığımız araştırmalarda münhasıran bu konuya tahsis edilmiş herhangi bir çalışma yahut benzer bir araştırma tespit edemedik. Böyle bir konunun ilk kez burada ele alındığını düşünüyoruz. Biz olmayan, bilinmeyen orijinal bir hususu çalışmada ortaya koyduğumuzu iddia etmiyoruz. Esasen burada adı geçen tefsirler tabakat, teracim, tezkire, mu'cem, fihrist gibi bibliyografya ve biyografi kitaplarında veya ilgili tezlerde, makale ve müstakil kitap çalışmalarında geçmektedir. Oralarda bulunan dağınık ve düzensiz bilgileri derleyip toplu bir halde ve belli bir düzen içinde, "müellifleri tarafından tamamlanmamış olmak" özelliklerini öne çıkararak Tefsir akademisyenlerinin dikkatine sunmak istedik. Çalışmada müellifi tarafından tamamlanmamış bütün tefsirlerin ele alındığı gibi bir iddia içinde değiliz. Böyle bir çalışma çok fazla yer tutacak ve bir makalenin sınırını ziyadesiyle aşacaktır. Sadece diğerlerine nispetle daha fazla öne çıtığını gördüğümüz tefsirleri inceledik. Bunların da mümkün olduğunca farklı bölgelerden, farklı dillerden, farklı zamanlardan ve farklı mezheplerden olmasına özen gösterdik. Çalışmanın sınırları açısından müellif ve tefsir hakkında kısa bilgiler vermekle yetindik. Müelliflerin hayatına kısaca yer vermemizin sebebi, çalışmanın bir bütünlük oluşturmasıdır. Ayrıca tefsirlerin neden yarım kaldığı, tamamlanmışsa kim tarafından ikmâl edildiği gibi hususlara da kısaca değindik. 


\section{Bahru'l-hakâik ve'l-meânî fî tefsiri's-seb'i'l-mesânî: Necmüddin Dâye (v. 654/1257)}

Müellifi tarafından tamamlanmadığını müşahede ettiğimiz ilk tefsirlerden biri Necmüddin Dâye'ye ait olan Bahru'l-hakâik ve'l-meânîfì tefsîri's-seb 'i 'l-mesânî adlı eserdir. Memleketi Rey'de doğduktan sonra eğitim almak üzere muhtelif beldeler gezen ve oralardaki âlimlerden dersler alan Dâye, tasavvuf hayatının önemli simalarından biridir. Necmeddin Kübrâ'nın yanında eğitim görmüş, hocasının Moğollarla yapılan savaşta şehit olması üzerine ve aynı zamanda Moğolların zulmünden kurtulmak için bölgeden ayrılmış, İran-Anadolu-Irak coğrafyalarında muhtelif beldelerde bulunmuştur. Konya'da Mevlana ve Sadreddin Konevî'yle mülâki olduğu belirtilmiştir. Son olarak Bağdat'a yerleşen ve hayatının geri kalan kısımlarını burada geçiren Dâye, 654/1257 yılında burada vefat etmiştir. ${ }^{1}$ Müellif Necmüddin Dâye, Bahru'l-hakâik ve'l-meânî fì tefsiri's-seb 'i'l-mesânî adında bir tefsir yazmıştır. ${ }^{2}$ Bazı kaynaklarda belirtildiğine göre bu tefsir önceleri Necmüddin Kübrâ (v. 618/1222) tarafindan yazılmıştır. Kübrâ, Kur'ân'ın başından 51. sûre olan Zâriyât sûresinin 17. âyetine kadarki kısmı tefsir etmiş, ancak gerisini yazmaya zaman bulamadan vefat etmiştir. Dolayısıyla tefsir eksik kalmıştır. Ancak onun ardından müridi Necmüddin Dâye tefsiri tamamlamaya kalkmış ve şeyhi Kübrâ’nın tarzı ve üslubu üzere 53. sûre olan Necm sûresinin başından başlayarak Kur'ân'ın sonuna kadarki kısımları tefsir etmiştir. Böylece tefsir 51. sûre olan Zâriyât'ın yarısı ile 52. sûre olan Tûr sûresi eksik kalmak üzere tamamlanmıştır. Daha sonra Alauddevle es-Simnânî (v. 736/1335), Kübrâ'nın eksik bıraktığı yer olan Zâriyât sûresi 17. âyetten başlayarak Kur'ân'ın sonuna kadar yeniden tefsir etmiştir. O da Kübrâ'nın tarzına, tavrına, üslubuna bağlı kalmıştır. ${ }^{3}$ Böylece bu eser üç müfessirin katkısı ve gayretiyle tamamlanmıştır. ${ }^{4}$ Ancak tefsirin aslında Kübrâ'ya değil, Dâye'ye ait olduğu belirtilmiştir ki yukarıda da bundan bahsettik. Buna göre tefsir Dâye tarafından yazılmıştır ve yanlışlıkla Kübrâ'ya atfedilmiştir. ${ }^{5}$ Nitekim

1 İsmail Paşa el-Bağdâdî, Hediyyetu'l-ârifin esmâu'l-müellifîn ve âsâru'l-musannifîn, (İstanbul: Matbaatu'l-behiyye, 1951), 2: 461; Muhammed Hüseyin ez-Zehebî, et-Tefsîr ve'l-müfessirûn, (elKâhire: Mektebetu vehbe, ts.), 2: 290-291; Mehmet Okuyan, "Necmeddîn-i Dâye", DİA, (İstanbul: Türkiye Diyanet Vakfı Yayınları, 2006), 32: 496-497; a.mlf., "Necmüddin Dâye ve Tasavvufî Tefsiri”, Ondokuz Mayls Üniversitesi İlahiyat Fakültesi Dergisi 8 (1996): 109-112; Süleyman Ateş, “Üç Müfessir Bir Tefsir”, Ankara Üniversitesi İlahiyat Fakültesi Dergisi 18 (1970): 89-90.

2 Mustafa b. Abdullah Hacı Halife Kâtip Çelebî, Keşfu'z-zunûn an esâmi'l-kutubi ve'l-fünûn, (Beyrût: Dâru ihyâi't-turâsi'l-arabî, ts.), 1: 224. Eserin yazılış gayesi ve muhtevası hakkında bilgi için bk. Halil Baltacı, 'Necmeddin Dâye'nin Bahru'l-Hakâik Adlı Tefsirinde İbadetlere Dair Bazı İşârî Yorumlar”, Hitit Üniversitesi İlahiyat Fakültesi Dergisi 10/20 (2011/2): 197-200.

3 Ateş, "Üç Müfessir Bir Tefsir", 86; Okuyan, Necmuddin Dâye ve Tasavvufí Tefsiri, 74.

4 Ateş, "Üç Müfessir Bir Tefsir", 86.

5 Hamid Algar, "Bahrü'l-Hakâik ve'l-Meânı̂”, DİA, (İstanbul: Türkiye Diyanet Vakfı Yayınları, 1991), 4: 515-516; Süleyman Gökbulut, Necmeddin Kübrâ ve Kübrevilik, (Doktora Tezi, Dokuz Eylül Üniversitesi, 2009), 113. 
Dâye, mukaddimede tefsiri Bahru'l-hakaik ve'l-maânî fî tefsiri 's-seb 'i'l-mesânî diye isimlendirdiğini belirtmiştir. Buna göre tefsir Dâye tarafindan başlatılmış, müellif -farklı yerler gösteriliyorsa da- Necm sûresi 8 . âyete veya buraya yakın yerlere kadar gelmiş, ${ }^{6}$ geri kalan kısmı ise Simnânî tarafından tamamlanmıştır. Simnânî her ne kadar hocasının tarzı üzere devam etmişse de iki müfessirin üslubu ve yaklaşımı arasında fark olduğu da söylenmiş̧ir. ${ }^{8}$

\section{Bahru'l-ulûm: Alâuddin es-Semerkandî (v. 860/1456)}

Müellifi tarafından tamamlanamamış diğer bir tefsir de Bahru'l-ulûm adlı tefsirdir. Eser, Semerkant'ta doğan Alâuddin Ali es-Semerkandî’ye aittir. Semerkandî, faklı beldelerdeki ilim ve irfan meclislerinden istifade etmiş ve son olarak Karaman'a yerleşmiştir. Derin bir tasavvufî hayat yaşadığı belirtilen müellif, Karaman'da 860/1456 y1lında vefat etmiş ve oraya defnedilmiştir. ${ }^{9}$ Alâuddin es-Semerkandî’ye ait olan Bahru'l-ulûm adlı eser, eksik kalmış tefsirlerdendir. Eser Fatiha'yla başlamakta, Mücâdele suresinde son bulmaktadır. İçinde pek çok faydalı malûmâtın olduğu tefsir, bu haliyle dört ciltten ibârettir. Tefsirde âyetler ve kelimeler tahlil ve tavzih edilmiş, tefsir vecihleri verilmiş, bilhassa belagât yönüne çok itina gösterilmiş, ara sıra mütasavvifâne bilgiler de serdedilmiştir. Müfessir, hadislere, sahâbe ve tâbiûn kavline bolca yer verdiği gibi, ayrıca aralarında Mukâtil b. Süleyman, Ebû Mansûr el-

6 Okuyan, "Bahru'l-Hakaik Tefsiri ve Müellifi Üzerine”, 121-122.

7 ez-Zehebî, et-Tefsîr ve 'l-Müfessirûn, 2: 290-291; Ateş, “Üç Müfessir Bir Tefsir”, 85-104.

8 ez-Zehebî, et-Tefsîr ve'l-Müfessirûn, 2: 291-292.

9 Ahmed b. Muhammed el-Ednevî, Tabakâtu'l-müfessirîn, thk. Süleyman b. Salih el-Hizî, (elMedîne el-Munevvere: Mektebetu'l-ulûm ve hikem, 1417/1997), 385; Kâtib Çelebi, Keşfü'zzünûn, 1: 225; Evliya Çelebi, Seyahatname (Anadolu, Suriye, Hicaz), (İstanbul: Devlet Matbaası 1935), 9: 318; Mecdi Mehmet Efendi, Şakâik-i Nu'mâniye ve Zeyilleri Hadâiku'ş-Şakâik, haz: Abdülkâdir Özcan, (İstanbul: Çağrı Yayınları, 1998), 102; Şemseddin Sami, Kâmusu'l-a 'lâm, (İstanbul: Mihran Matbaas1, 1311), 4: 3170; Hayreddin b. Mahmud b. Muhammed Ali b. Faris ez-Ziriklî, el-A'lâm kâmûsu terâcimi eşheri'r-ricâli ve'n-nîsâi mine'l-arabî ve'l-musta'rabîn ve'l-musteşrikîn, (Beyrût: Dâru'l-ilim li'l-mellayin, 2002), 5: 32; el-Bağdâdî, Hediyyetu'larifin, 1: 733; Bursalı Mehmed Tahir, Osmanlı Müellifleri, (Ankara: Bizim Büro Basımevi, 2009), 1: 60; Ömer Rıza Kehhâle, Mu'cemu'l-müellifin, (Beyrût: Dâru ihyâi't-turâsi'l-arabî, ts.), 7: 261; Ömer Nasuhi Bilmen, Büyük Tefsir Tarihi Tabakâtü'l-Müfessirîn, (İstanbul: Bilmen Yayınlar1, 1974), 2: 595; Seyyid Alaeddin Ali b. Yahya es-Semerkandi, Muhtasar Bahru'l-Ulûm Tefsiri (İlimler Deryasl), trc. Ali Kara, (Ankara: Mutlu Ticaret, 1421), 1: VII-IX; İshak Yazıc1, "Bahru'l-Ulûm", DİA, (İstanbul: Türkiye Diyanet Vakfi Yayınları, 1991), 4: 517-518; İbrahim Hakkı Konyal1, Âbideleri ve Kitâbeleri ile Karaman Tarihi Ermenek ve Mut Âbideleri, (İstanbul: Baha Matbaas1, 1967), 213; Yunusdjon Olimov, Alaeddin es-Semerkandi'nin Bahru'l-Ulûm Adlı Tefsiri ve Kaynakları, (Doktora Tezi, Ankara Üniversitesi, 2010), 5-7; M. Akif Erdoğru, "Şeyh Ali Semerkandî Üzerine Yeni Bilgiler”, 60. Yılında İlim ve Fikir Adamı Prof. Dr. Kâzîm Yaşar Kopraman'a Armağan, haz. E. Semih Yalçın, (Ankara: Berikan Yayınları, 2003 ), 324. 
Mâturidî, ez-Zemahşerî, Fahreddin Râzî gibi müfessirlerin tefsirlerinin de bulunduğu daha başka bazı kaynaklardan da yararlanmıştır. Tefsirin geri kalan kısmı Osmanlı âlimi Esam Karamanî tarafından tamamlanmıştır. Karamanî, Semerkandî’nin tefsirinin Mücadele sûresinden Kur'ân'ın sonuna kadar olan kısımlarını onun tarzı üzere tefsir etmiş, böylece tefsir ikmâl edilmiştir. ${ }^{10}$ Cemaleddin Aksarayî̀nnin bu tekmileyi yaptığı ileri sürülmüşse de doğru olan, Esam Karamanî’nin bu işi yaptığıdır. ${ }^{11}$

\section{Tefsiru'l-Celâleyn: Celâluddin el-Mahallî (v. 864/1459)}

Müellifi tarafından tamamlanmadığ için yarım kalmış daha sonra tamamlanmış en önemli tefsirlerden ${ }^{12}$ biri de Celaleyn Tefsiri'dir. Tefsir iki Celal tarafından yazılmıştır. İlk olarak Celâleddin el-Mahallî tarafından yazılmaya başlanmıştır. Mahalli, Mısırlı olup dönemin önemli âlimlerinden dersler almış, kendisi de çok sayıda öğrenci yetiştirmiştir. Tefsiri tamamlayan Celaleddin es-Suyûtî de bunlardan biridir. Müellif, 864/1459 yılında Mısır'da eserini tamamlayamadan vefat etmiştir. ${ }^{13}$ Yapılan çalışmalardan anlaşıldığı kadarıyla Mahallı̂ eserinin ancak yarısını yazabilmiştir. Onun vefatı üzerine öğrencisi Celâleddin es-Suyûtî, eseri hocasının tavrı ve tarzı üzere yazıp ikmâl etmiştir. Suyûtî’nin yazdığı kısım incelendiğinde kendisinin, hocasının yöntemine titiz bir şekilde riayet etmesi sayesinde hangi kısmın Mahallî’ye, hangi kısmın Suyûtî’ye ait olduğunu ayırt etmek mümkün gözükmemektedir. ${ }^{14}$ Zaten bu yüzden Mahallî̀nin önce Kur'ân'ın yarsından yani Kehf sûresinin başından itibaren eserini yazmaya başladığı, sonuna kadar geldiği, bu şekilde Kur'ân'ın son sûresi olan Nas sûresini tefsir ettikten sonra Kur'ân'ın başından yani Fâtiha sûresinin tefsirinden başlayarak ilk yarısını yazmaya başladığı, fakat Fâtiha'yı bitirdikten sonra geri kalan kısımları yazmaya firsat bulamadan vefat ettiği belirtilmektedir. Buna göre eserin son yarısı Mahallî’ye, ilk yarısı

10 Ziya Demir, XII-XVI Y.Y. Arası Osmanlı Müfessirleri, (İstanbul: Ensar Neşriyat, 2007), 163; Muhammed Abay, “Osmanlı Dönemi Dirayet Tefsirleri”, Türkiye Araştırmaları Literatür Dergisi (TALID), 9/18 (2011): 95-96.

11 Demir, XII-XVI Y.Y. Arası Osmanlı Müfessirleri, 163.

12 Bk. Kâsid Yâsir ez-Zebîdî, "Menhecu'l-Celâleyn fî̀ tefsîri'l-Kur'âni'l-Kerîm”, Adâbu'r-Râfidîn 5 (1974): 125-126 (125-150).

13 Bk. Celaleddin es-Suyûtî, Husnu'l-muhâdere fî târîhi Mısır ve'l-Kâhire, thk. Muhammed Ebu'l-Fadl İbrahim, (Mısır: Dâru ihyâi'l-kutubi'l-arabî, 1387/1967) 1: 443-444; Şemsuddin b. Muhammed ed-Dâvûdî, Tabakâtu'l-müfessirîn, thk. Lecne mine'l-ulemâ, (Beyrût: Dâru'lkutubi'l-ilmiyye, ts.) 2: 84-85; ez-Ziriklî, el-A'lâm, 5: 333; el-Ednevî, Tabakâtu'l-müfessirîn, 336; Bilmen, Büyük Tefsir Tarihi, 2: 596; ez-Zehebî, et-Tefsir ve'l-müfessirûn, 1: 237; Şükrü Arslan, "Mahallî", DIA, (İstanbul: Türkiye Diyanet Vakfı Yayınları, 2003), 27: 326.

14 ez-Zehebî, et-Tefsir ve'l-müfessirûn, 1: 239. 
yani Bakara sûresinin başından İsrâ sûresinin sonuna kadar ki kısmı Suyûtî’ye ait olmaktadır. ${ }^{15}$ Hâlbuki bunun tersi de söylenmiştir. Buna göre ilk yarısı Mahallı̂’ye, son yarısı Suyûtî’ye aittir. ${ }^{16}$ Ancak kaynakların çoğu Kehf'ten aşağısının Mahallı̂’ye, Bakara'dan İsrâ sonuna kadarki kısmın Suyûtî’ye ait olduğunu söylemektedir. ${ }^{17}$ Esasen Suyûtî’nin kendisi de bunu belirtmektedir. ${ }^{18}$ Bu husus, Suyûtî’nin hocasının tarzına, üslubuna ve yöntemine ne kadar bağlı kaldığını göstermektedir. Eser, Suyûtî'nin ikmâlinden sonra iki Celâl'a ait olması hasebiyle Tefsîru'l-Celâleyn adı ile meşhur olmuş, defalarca istinsah edilmiş, 20. yüzyıldan itibaren pek çok baskısı yapılmıştır. Bugün eserin çok sayıda farklı baskıları mevcuttur. Ayrıca eser çok sayıda şerh ve haşiyeye de konu olmuştur.

\section{Tefsîru İbn Kemal: İbn Kemal Paşa (v. 942/1533)}

Osmanlı şeyhülislamı olan İbn Kemal (v. 942/1533), ilme meraklı bir zattır. Önceleri askeriyeye intisap etmişse de sonra ilmiye sınıfına katılmış, iyi bir eğitim alarak kendini yetiştirmiştir. Osmanlı şeyhülislamlarından olup, eğitim-öğretim faaliyetleri yanında ayrıca muhtelif eserler de kaleme almıştır. ${ }^{19}$ Bunlardan biri de

15 ez-Zehebî, et-Tefsir ve'l-müfessirûn, 1: 237-239; Abdulcelil Candan, "Celâleyn Tefsirine Eleştirel Bir Yaklaşım”, Yüzüncü Yıl Üniversitesi İlahiyat Fakültesi Dergisi 3 (2000): 343; Şükrü Arslan, “Celâleyn Tefsirinin İsnadı ve el-Mahallî’nin Bakara Sûresinden Yaptığı Tefsiri”, Atatürk Üniversitesi İlahiyat Fakültesi Dergisi 10 (1991): 155-159; Abdurrahman Altuntaş, Celâleyn Tefsiri ve Metodu, (Yüksek Lisans Tezi, Ankara Üniversitesi, 2004), 44.

16 ez-Zehebî, et-Tefsir ve'l-müfessirûn, 1: 238; Ali Akpınar, "Celâleyn Tefsiri ve Müellifleri”, Cumhuriyet Üniversitesi Illahiyat Fakültesi 2 (1998): 181-182.

17 Bk. Süleyman el-Cemel, el-Futûhâtu'l-ilâhiyye bi tavdîhi tefsiri'l-Celâleyn, (Misır: el-Matbaatu'lâmire, 1303), 2: 711-712; Muhammed Ahmed Ken'ânî, Kurretu'l-ayneyn ala tefsiri 'l-Celâleyn, (Beyrût: Şeriketu dâri'l-beşâiri'l-İslâmiyye 1918/1997), 380.

18 el-Kur'ânu'l-Kerîm bi'r-resmi'l-Osmanî ve bi hâmişihi tefsiru'l-İmameyn el-Celileyn, haz. Abdulkadir Arnâût, (Dimaşk: Dâru İbn Kesir, ts.), 294.

19 Ebû'l-Hayr İsâmüddin Ahmed b. Mustafa Taşköprüzâde, eş-Şekâiku'n-nu'mâniyye fì ulemâi'ddevleti'l-Osmâniyye, (Beyrût: Dâru'l-tutubi'l-arabî, 1395/1975), 227; Kehhâle, Mu'cemu'lmüellifin, 1: 238; Bilmen, Büyük Tefsir Tarihi, 2: 635-636; Ilmiyye Salnamesi, haz. S.A.KaramanA.N.Galitekin-C.Dadaş, (İstanbul: 1998), 299; Ahmet Uğur, İbn-i Kemal, (Ankara: Kültür ve Turizm Bakanlığı Yayınları, 1987), 1-24; Mehmet Sofuoğlu, Tefsire Giriş, (İstanbul: Çağrı Yayınları, 1981/1401), 364-367; Demir, Osmanlı Müfessirleri, 238-241; Süleyman Mollaibrahimoğlu, Yazma Tefsir Literatürü, (İstanbul: Damla Yayınları, 2007), 457; Murat Ustakurt, İbn Kemal Paşa'nın “Tefsiru'l-Fâtiha” Adlı Eseri, (Yüksek Lisans Tezi, Marmara Üniversitesi, 2009), 26, 38; Mustafa Kılıç, İbn Kemâl, Hayatı, Tefsir Dair Eserleri ve Tefsirindeki Metodu, (Doktora Tezi, Atatürk Üniversitesi, 1981), 1-87; Osman Nuri Küçükibrahimoğlu, “İbn Kemal Paşa”, Diyanet İşleri Başkanlığı Dergisi 11/2 (1972): 115-118; Mustafa Kılıç, “İbn Kemal Paşa (H. 873-949/M. 1468-69-1534)”, Eyüp Sultan Sempozyumu VI, haz. İrfan Çalışan, (İstanbul: Eyüp Sultan Belediyesi, 2003), 153-157; Şerafettin Turan, "Kemalpaşazâde", DIA, (İstanbul: Türkiye Diyanet Vakfı Yayınları, 2002), 25: 238-239. 
kendi adına nispetle bilinen Tefsîru İbn Kemal Paşa adlı önemli eseridir. ${ }^{20}$ Eser oldukça hacimli bir tefsirdir. Müellif Osmanl1/Türk âlimi olmakla birlikte eserini Arapça olarak kaleme almıştır. Tefsir eksik olup Kur'an'ın başından Sâffât suresine kadarki kısımları kapsamaktadır. ${ }^{21} \mathrm{O}$ yüzden eser aynı zamanda Tefsîru 'l-Kur'ân ilâ Sûreti's-Sâffât diye de bilinmektedir. Ancak bazı nüshalarda İbn Kemal'in Sâd sûresini de tefsir ettiği belirtilmiştir. Buna göre tefsir Sâd sûresinin sonuyla bitmektedir. ${ }^{22}$ Bununla birlikte tefsiri basanlar bu sûreyi eklememişler, tefsiri Saffât sûresiyle bitirmişlerdir. ${ }^{23}$ Müellif Kur'ân'’n tamamını tefsir etmeyi, ortaya kâmil bir tefsir koymayı murad ettiği halde ömrü vefa etmemiş ve tefsirini tamamlayamadan vefat etmiştir. Ardından tefsirini ikmâl etmek, geri kalan kısımları aynı tarz ve üslup üzere tefsir etmek isteyen kimse çıkmamıştır. Tefsir eksik haliyle 9 cilt olarak basılmıştır. ${ }^{24}$ Dokuzuncu cilt İbn Kemal'in daha önce yazmış olduğu Mülk, Nebe, Nâziât ve Târık surelerinin tefsiriyle fihristleri kapsamaktadır.

\section{Tercümânu'l-Kur'ân: Sıddık Hasan Han (v. 1307/1890)}

Sıddık Hasan Han, Hind Altkıtasında yetişmiş âlimlerden biridir. Sıddık Hasan Han Kınnevc şehrinde doğmuş, ilk eğitimine orada başlamıştır. Babasını küçük yaşta kaybetmiş, civar şehirlerde eğitimini sürdürmüş, muhtelif beldeler gezmiş olan Sıddık Hasan Han, daha sonra yerleştiği ve bakanlık dâhil üst düzey görevler yürüttüğü Bopal'da sultan Şah Cihan Begüm'le evlenmiştir. Daima İngilizlerin takdir ve desteğini almış, bu arada Sultan II. Abdülhamid de evliliğinden dolayı kendisini tebrik edip Osmanlı nişanı takdim etmiştir. Ancak bir süre sonra İngilizler Sıddık Hasan Han'a muhtelif bahanelerle müdahale etmişler, onu görevden almışlar, bütün yetkilerini iptal edip, bütün makam ve nişanlarını geçersiz saymışlardır. Ayrıca Şah Cihan’la evliliğgini de bitirmişlerdir. Sıddık Hasan Han

20 Enver Arpa, “Şeyhülislam Kemal Paşazade ve Tefsir Anlayışı”, X. Kur 'ân Sempozyumu Kur'ân ve Eğitim 12-13 Mayls 2007/Tokat, ed. Yok, (Ankara: Fecir Yayınları, 2008), 196.

21 Abay, "Osmanlı Dönemi Dirayet Tefsirleri”, 101-102; Yunus Abdulhayy Ma, Tahkîk ve dirâsetu sûretey el-Fâtiha ve'l-Bakara min tefsiri İbn Kemâl Başa t. 940, (Yüksek Lisans Tezi, elCâmiatu'l-İslâmiyye bi'l-Medineti'l-Münevvere, 1411), 53; Muhammed İbrahim Abdulhalim Muhammed, “İbn Kemal Başa ve menhecuhu fi't-tefsîr”, Havilyyetu kulliyyeti'd-dirâsâti'lİslâmiyye ve'l-arabiyye li'l-benât bi'l-İskenderiyye 6/35 (2019): 131.

22 Kılıç, İbn Kemâl, Hayatı, Tefsir Dair Eserleri ve Tefsirindeki Metodu, 114-115.

23 Şemsuddin Ahmed b. Süleyman İbn Kemal Başa er-Rûmî el-Hanefî, Tefsîru İbn Kemal Başa, thk. Mahir Edib Habbûş, (İstanbul: Mektebetu'l-irşâd, 1439/2018), 8: 532.

24 Şemsuddin Ahmed b. Süleyman İbn Kemal Başa er-Rûmî el-Hanefî, Tefsîru İbn Kemal Başa, thk. Mahir Edib Habbûş, (İstanbul: Mektebetu'l-irşâd, 1439/2018). 
bu ağır travmadan bir süre sonra 59 gibi genç sayılabilecek bir yaşta vefat etmiştir. ${ }^{25}$ Çok sayıda önemli eser telif eden Sıddık Hasan Han, Arapça yazdığı tefsirler yanında bir de Urduca olarak Tercümânu'l-Kur'ân bi letâifi'l-beyân adıla eserini yazmıştır. Müellif Fâtiha sûresinden Kehf sûresine kadarki kısım ile Tebâreke ve Amme cüzlerinin tefsirini yapmış, ancak geri kalan kısımları tefsir edemeden vefat etmiştir. Dolayısıyla tefsir müellifin tamamlayamadığı eksik bir eserdir. Tefsir bu haliyle 7 cilt olarak basılmıştır. Daha sonra müellifin öğrencilerinden Muhammed b. Hâşim ve Zülfikar Ahmed Bopâlî, Meryem sûresinin başından Tahrim sûresinin sonuna kadarki kısmı yani hocalarının eksik bıraktı̆̆ı yerleri onun tarzı ve üslubunu esas alarak yapmışlardır, böylece tefsir tamamlanmıştır. Öğrencilerinin hazırladığı kısım da sekiz cilt olarak basılmıştır. Sıddık Hasan Han, eserinde Şah Abdulkadir Dihlevî'nin Urduca tercümesini ve Mûdihu'l-Kur' ân adlı tefsirindeki küçük bazı açıklamalarını, Şah Veliyyullah'ın Farsça tercümesini, İbn Kesîr'in tefsirini, Şevkânî'nin Fethu'l-Kadir adlı tefsirini ve kendi tefsiri olan Fethu'l-Beyân'1 kullanmış, bunlarda gerekli gördüğü bilgileri bir araya getirerek tefsirini hazırlamıştır. Açıklama yapma gereği duyduğu yerlerde (faide) anlamında (ف) harfini koyarak açıklamalar yapmıştır. ${ }^{26}$

\section{Tefsîru'l-Menâr/Tefsiru'l-Kur'âni'l-Hakîm: Muhammed Abduh (v. 1322/1905) ve Muhammed Reşid Rıza (v. 1353/1935)}

Muhammed Abduh, son dönem İslam fikir ve düşünce hareketinin en önemli isimlerinden biridir. Mısır'da doğup yetişmiştir. Ezher Üniversitesi'nde aldığı eğitim yanında ayrıca özel hocalardan da ders almıştır. Cemaleddin Efgânî’yle (v. 1315/1897) tanışması, onun duygu ve düşünce dünyasını tamamen değiştirmiş̧ir. Nitekim onunla birlikte Paris'te el-Urvetu'l-vuskâ dergisini çıkarmıştır. ${ }^{27}$ Abduh, Müslümanların içinde bulundukları geri kalmışlıktan kurtulmaları için 1slahatın

25 Abdurrezzâk el-Baytâr, Hilyetu'l-beşer fì târîhi'l-karni's-sâlis aşer, thk. Muhammed Behcet el-Baytâr, (Dimaşk: Mecmau'l-luğati'l-arabiyye, 1382/1963), 2: 738-741; Zekî Muhammed Mücâhid, el-A'lâmü'ş-şarkıyye fi'l-mieti'r-râbia aşere el-hicriyye, (Beyrût: Dâru'1-ğarbi'1İslâmî, 1994),1: 385-386; Seyyid Muhammed İctiba en-Nahvî, "el-Emîr Siddîk Hasan Hân", Mecelletu sakâfeti 'l-Hind el-fasliyye 52/2 (2001): 28-35 (28-39); Abdullah b. İbrahim el-Ensârî, "Ta'rîf bi'l-kitâb ve müellifihi”, Fethu'l-beyân fì makâsidi'l-Kur'ân, haz. Abdullah b. İbrahim el-Ensârî, (Beyrût: el-Mektebetu'l-asriyye, 1412/1992), 1: 3-5; Abdülhamit Birışık, Hind Altkıtası Düşünce ve Tefsir Ekolleri, (İstanbul: İnsan Yayınları, 2012), 144-146; Tâyir, Neylu's-sâirîn fî tabakâti'l-müfessirîn, 440; Abdülhamit Birış1k-Cüneyt Eren, "Sıddîk Hasan Han”, DİA, (İstanbul: Türkiye Diyanet Vakfı Yayınları, 2009), 37: 92.Sabğatullah Tayfur, Siddîk Hasan Han ve Tefsiri Fethu'l-Beyân, (Doktora Tezi, Dicle Üniversitesi, 2018), 7-10.

26 Birışı, Hind Altkıtası Düşünce ve Tefsir Ekolleri, 146-147. Örnekler için bk. Aynı eser, 148-154.

27 Bk. Hilal Görgün, “el-Urvetü’l-Vüskâ”, DİA (İstanbul: Türkiye Diyanet Vakfı Yayınları, 2012), 42: 186-188. 
şart olduğunu, ancak bunun eğitim yoluyla olması gerektiğini söylüyordu. Bunun siyaset yoluyla olması gerektiğini düşünen Efgânî'yle yolları ayrıldı. Mısır'da Ezher örneğinde bu düşüncesini gerçekleştirmeye çalıştı. Yanına gelen Muhammed Reşid Rıza'nın da teşvikiyle fikir ve düşüncelerini çıkardıkları el-Menâr adlı dergide neşretti. Bu arada yine Rıza'nın teşvik ve desteğiyle Kur'ân'ı tefsir etmeye başladı. Onun yaptığı tefsirleri Reşid Rıza yazıya geçiriyor, çalışmaları Abduh'un kontrolünden geçtikten sonra Menar dergisinde yayınlanıyordu. Fâtiha sûresinden itibaren başlayan tefsir, Nîsâ sûresinin 124. âyetine kadar devam etti. Bu arada Abduh vefat etti. Böylece tefsir eksik bir eser olarak kaldı. Ancak Reşid Rıza, hocasının vefatından sonra hocasının tarzı üzere tefsiri kaldığı yerden yani Nîsâ sûresinin 124. âyetinden itibaren yazmaya devam etti. ${ }^{28}$

Muhammed Reşid Rıza, Lübnan'da doğmuştur. Küçüklüğünde muhtelif eğitim kurumlarında öğrenim görmüştür. Önceleri vaaz ve irşad faaliyetlerinde bulunmay tercih etmiş ve insanlara tasavvuf ve zühd hayatına göre yaşamalarını, dünyaya değil ahirete yönelik ameller yapmalarını tavsiye etmiştir. Babasının kitapları arasında Abduh ve Efgânî'nin çıkardığı el-Urvetu'l-vuskâ dergisinin birkaç nüshasını görüp okuyunca adeta dünyası değişmiş, fikirlerini değiştirmiş ve dünya hayatına yönelik faaliyetlerde bulunmaya, Müslümanları içinde bulundukları geri kalmışlıktan kurtaracak çalışmalar içine girmeye karar vermiştir. Bunun için Mısır'a gitmiş ve Abduh'un öğrencisi olmuş, sonra el-Menar adında bir dergi çıkarmış ve Abduh ile birlikte orada ihya ve islaha yönelik yazılar neşretmiştir. Bu arada yukarıda geçtiği üzere Abduh'a tefsir yazmasını telkin etmiştir. Reşid Rıza daha önce zikredildiği üzere hocasının vefatından sonra tefsiri tamamlamaya çalışmıştır. Fakat çok hareketli bir hayat geçirmiş, tefsir yazımına fazla zaman ayıramamıştır.

28 Bk. Muhammed Reşid Rızâ, Târîhu'l-Üstâzi'l-İmâm Muhammed eş-Şeyh Abduh ve fỉhi tafsîlu sîretihi ve hülâsetu sîreti mûkizi'ş-şarki ve hakîmi'l-İslâmi es-Seyyid Cemâluddin el-Afgânî, (elKâhire: Dâru'l-fadîle, 1427/2006), 1: 13-497; Emin, Zuamâu'l-lslâh fi'l-asri'l-hadîs, 280-337; Fehd b.Abdurrahman b. Süleyman er-Rûmî, Menhecu'l-medresti'l-akliyye el-hadîse fi 't-tefsîr, 2. Bask1, (er-Riyâd: Müessesetu'r-risâle, 1403/1983), 1: 124-169; Ignaz Goldziher, Mezâhibu 'ttefsir el-İslâmî, trc. Abdulhakim en-Neccâr, (Misır: Mektebetu'l-hancî, 1374/1955), 348-354; Osman Keskioğlu, "Muhammed Abduh (1266-1323/1849-1905)", Ankara Üniversitesi Ilahiyat Fakültesi Dergisi 18 (1970): 109-136; Mehmet Zeki İşcan, Muhammed Abduh'un Dinî ve Siyâsî Görüşleri, (Doktora Tezi, Atatürk Üniversitesi, 1997), 1-61; M. Sait Özervarl1, "Muhammed Abduh", DİA, (İstanbul: Türkiye Diyanet Vakfi Yayınları, 2005), 30: 482-487; Muhammed elFâdıl İbn Âşûr, et-Tefsîr ve ricâluhu, (el-Kâhire: Mecmau'l-buhûs el-İslâmiyye, 1390/1970), 160-176; Munî' b. Abdulhalim Mahmûd, Menâhicu'l-müfessirîn, (el-Kâhire: Dâru'l-kitâbi'l-Mısrî - Beyrût: Dâru'l-kitâbi'l-Lübnânî, 1421/2000), 305-314; Fehd b. Abdurrahman b. Süleyman er-Rûmî, Itticâhâtu't-tefsîr fi'l-karni 'r-râbi' 'aşer, (Beyrût: Müessestur'r-risâle, 1418/1997), 2: 803-809; Halil Taşpınar, "Muhammed Abduh Bibliyografyası Üzerine Bir Deneme”, Cumhuriyet Üniversitesi Illahiyat Fakültesi Dergisi 7/2 (Aralık 2003): 261-289. 
Muhtelif memleketlere gitmiş, ilim ve siyaset adamlarıyla görüşmeler yapmıştır. Bir yandan da Menâr dergisinin neşrini sürdürmüştür Bütün bu hareketli hayatının içinde tefsiri de yazmaya devam etmiştir. Reşid Rıza hocasının vefatından 30 yıl sonra 1935 yılında vefat etmiştir. ${ }^{29} 30$ yılda Nîsâ sûresinin 125. âyetinden Yûsuf sûresinin 52. âyetinin sonuna kadar gelebilmiştir. Söz konusu âyetin sonunda 1353 yılı Safer ayında bu cildi yazmaya başladığını ve 1354 yılının Muharrem ayının sonlarında da tamamladığın belirtmiştir. Geri kalan kısımları da Allah'ın rızasına muvafik bir şekilde tamamlaması için kendisine yardım etmesini istediğine dair not düşmüştür. ${ }^{30}$ Fakat o sıralar Suudi Arabistan'dan Mısır'a dönerken yolda geçirdiği rahatsızlık sebebiyle hayatını kaybetmiş ve eser bir kez daha eksik kalmıştır. Anlaşılan Reşid Rıza son zamanlarda tefsire ağırlık vermeye başlamış, nitekim bir y1l gibi bir süre içerisinde bir cildi tamamlamıştır. Şayet diğer ciltleri de bu süratte yazabilseydi muhtemelen tefsir eksik kalmayacak ve Reşid Rıza tarafından tamamlanmış olacaktı. Eser bu şekliyle 12 cilt halinde basılımıştır. ${ }^{31} 12$ cüzün 12 ciltte sona ermesinden hareketle tefsirin tamamlanmış olması halinde 30 cüzün yaklaşı 30 cilt tutması beklenirdi. Tefsîru'l-Menâr olarak da bilinen Tefsîru'l-Kur' âni'l-Hakîm, tefsir tarihinde müellifleri tarafından tamamlanamamış bir tefsir olarak yerini almıştır.

\section{Dâi'l-amel li yevmi’l-emel: Muhammed b. Yusuf b. İsâ b. Salih Ettafeyyiş} (v. 1332/1914)

İbaziyye mezhebine mensup olan müfessir Cezayir' de doğup büyümüş ve orada yetişmiştir. Başta kendi ailesindekiler olmak üzere bölgede bulunan âlimlerden dersler almış, pek çok kitap okuyup incelemiştir. Müfessir bir yandan bölgede vaaz ve irşat faaliyetlerinde bulunurken, bir yandan da öğrenci yetiştirip eser telif etmiştir. Onun sayesinde Hariciliğin kollarından biri olan İbaziyye yeniden canlanmıştır. Bir asra yakın yürüttüğü bu faaliyetlerini 1332/1914 yılında ölünceye

29 El-Emîr Şekib Arslan-Emîr el-Beyân, es-Seyyid Reşid Rızâ ev ihâu erbaîne sene, nşr. Midhat Yûsuf es-Seb', (el-Kâhire: Dâru'l-Fadîle, ts.), 4, 6, 23-102; er-Rûmî, Menhecu'l-medresti'lakliyye el-hadîse fi 't-tefsîr, 1: 171-182; M. Sait Özervarl1, "Reşid Rıza", DİA, (İstanbul: Türkiye Diyanet Vakfı Yayınları, 2008), 35: 14-18; Ez-Ziriklî, el-A'lâm, 6: 126; Özgür Kavak, Reşid Rıza'nın Fıkıh Düşüncesi Çerçevesindeki Görüşleri, (Doktora Tezi, Marmara Üniversitesi, 2009), 23-68; Mahmûd, Menâhicu'l-Müfessirîn, 316.

30 Muhammed Reşid Rıza, Tefsiru'l-Kur'âni'l-Hakîm, (Mısır: Matbaatu'l-menar, ts.), 12: 324.

31 Fehd b.Abdurrahman b. Süleyman er-Rûmî, Buhûs fì Usûli t-Tefsîr ve Menâhicih, (er-Riyâd: Mektebetu't-Tevbe, ts.), 159-160. 
kadar sürdürmüştür. Müellifin pek çok eseri içinde üç tane de tefsir vardır. ${ }^{32}$ Bunlar Dâi'l-amel li yevmi'l-emel, Himyânu'z-zâd ilâ dâri'l-meâd ve Teysîru't-tefsir adlı eserlerdir. Bunlardan Himyân ile Teysîr tam tefsirlerdir. Ancak Dâi'l-amel eksik kalmış bir eserdir. Müellif bu eserini 32 cilt olarak planlamış, ancak biraz ihmal, biraz da başka eserlerle meşguliyet yüzünden tefsir eksik kalmıştır. Dâi'lamel, Ettafiyyiş'in Himyân adlı tefsirinden sonra, Teysîr adlı tefsirinden de önce kaleme alınmış olmalıdır. Elde bulunan yazma hali, Rahmân ile Nas sûresi arasını kapsamaktadır. ${ }^{33}$ Bu husus müellifin eserine Rahman suresinden başlamış olması ihtimalini akla getiriyor.

\section{Tercümânu'l-Kur'ân: Ebu'l-Kelâm Azâd (v. 1377/1958)}

Ebu'l-Kelam Azad Hint asıllı bir baba ile Arap asıllı bir annenin çocuğu olarak Mekke'de dünyaya gelmiştir. Mekke'de başladığı eğitimini, ailesinin Hindistan'a taşınması üzerine orada sürdürmüştür. Ana dili olan Arapça yanında Farsça, Urduca, Türkçe, İngilizce ve Fransızcayı da ileri seviyede öğrenmiştir. Bu arada siyasetle iç içe yaşamıştır. İran, Osmanlı ve daha başka ülkelere ziyaretler yapmış, buralardaki âlim ve entelektüellerle görüşmüş, bu arada Jön Türklerle de iyi münasebetler kurmuştur. ${ }^{34} 1915$ yılında bir tefsir yazmaya başlayacağını belirtmiştir. Nitekim Tercümanu'l-Kur'an adlı bu eserini Hud sûresine kadar getirmişti. Ancak 19161920 yılları arasında İngilizler tarafından Hindistan'da hapse atılınca çalışmalarıyla ilgilenemedi. Diğer birçok eseri gibi Tercümanu'l-Kur'ân adlı eseri de kaybolup gitti. Yine Nisa sûresine kadar getirdiği Tefsiru'l-beyân adındaki tefsiri de kayboldu. Hapisteyken Urduca Kur'ân tercümesini hazırladı, eserini 1921 yılında ikinci

32 Muhammed Akki Alvânî, Muhammed b. Yusuf Etfayş ve menhecuhu fi tefsiri ’t-teysîr, (Yüksek Lisans Tezi, el-Ma'hed el-Vatani li Usûli'd-Din el-Cezâyir, 1411/1990-1991), 54-89; Sabri Hizmetli, "Ettafeyyiş", DİA, (İstanbul: Türkiye Diyanet Vakfı Yayınları, 1995), 11: 500-501; Güven Ağırkaya, Ettafeyyiş' in Himyânu'z-Zâd ilâ Dâri'l-Meâd Adlı Tefsiri ve Harici Yorumları, (Doktora Tezi, Erciyes Üniversitesi, 2019), 53-62.

33 Nurullah Çakmaktaş, İbâzî Müfessir Ettafayyiş ve Teysîru't-Tefsir Adlı Eseri, (Yüksek Lisans Tezi, Marmara Üniversitesi, 2009), 23; Alvânî, Muhammed b. Yusuf Etfayş ve Menhecuhu fi Tefsiri 't-Teysîr, 93.

34 Adil Nüveyhid, Mu'cemu'l-müfessirîn min sadri'l-İslâm hatta 'l-asri'l-hâdir, (Misır: Müessesetu Nüveyhid es-sakâfiyye, 1409/1988), 1: 36; Christian W. Troll, "Mevlânâ Ebu'l-Kelâm Âzâd (1888-1958): Çoğulcu Bir Ülke ve Dünya İçinde Yaşayıp Algılanan İslam”, trc. Şaban Ali Düzgün, İslâmî Araştırmalar 7/1 (Kış 1993-94): 23-24; Azmi Özcan, "Ebü'l-Kelâm Âzâd", DİA, (İstanbul: Türkiye Diyanet Vakfı Yayınları, 1994), 10: 335-336; Birışık, Hind Altkıtası Düşünce ve Tefsir Ekolleri, 308-310; Türkkaya Ataöv, "Mevlânâ Âzâd”, Ankara Üniversitesi Siyasal Bilgiler Fakültesi Dergisi 50/1-2 (1995): 69-75 (69-76); Zekai Kardaş, Ebû'l-Kelâm Âzâd ve el-Hilâl Gazetesi Çerçevesinde Türkiye ve Türkler, (Doktora Tezi, İstanbul Üniversitesi, 2011), 11-55; Fatma Sel, “Mevalana Ebu'l-Kelam Azad”, Haksöz 34 (1994): 26-32 (24-33). 
kez tutuklandığında basılmak üzere matbaaya vermişti, ancak bu nüsha da orada kayboldu ve bir daha bulunamadı. Bütün bunlar onun tefsir yazmadaki azmini yok etmedi. Sağlığı ve morali bozulduğu halde yeniden Kur'ân'1 tefsire koyuldu. 1930 yılında yeninden yazdığı Tercümânu'l-Kur'ân'ın ilk cildini yayınladı. Bu cilt En'am sûresinin sonuyla bitiyordu. 1936 yılında tefsirinin A'raf sûresiyle başlayıp Mü'minun sûresinin sonuyla biten ikinci cildi yayınlandı. Geri kalan sûrelerin tefsirini içeren 700 sayfalık üçüncü cilt maalesef yayınlanacağ belirtilmiş olduğu halde basılmamış, üstelik müsveddeleri de bulunamamıştır. Böylece Azad'ın Tercümânu'l-Kur'ân adlı eseri eksik bir tefsir olarak kalmıştır. Daha sonraları öğrencilerinden Mevlana Muhammed Abduh, dergilerdeki makalelerinden yararlanarak üçüncü cildi tamamlayıp 1981 yılında basmıştır. Tefsirin son baskısında birinci cilt Fâtiha'dan En'âm sûresine kadar, ikinci cilt A'râf-Mü'minûn, üçüncü cilt de Nur ve Nas sûreleri arasını kapsamaktadır. Bu arada ikinci tefsiri olan Tefsiru'l-beyân ise eksik ve kayıp bir tefsir olarak kalmıştır. ${ }^{35}$

\section{Edvâu'l-beyân fî izâhi'l-Kur'âni bi'l-Kur'ân: Muhammed el-Emin eş-Şinkîtî} (v. 1393/1973)

Muhammed el-Emin eş-Şinkîtî, Moritanya'nın Şinkît bölgesindendir. Şinkîtî, ilimle meşgul olan bir ailenin ve çevrenin çocuğu olup küçük yaşlarda ailesinden ve bölgedeki hocalardan dersler alarak kendini yetiştirmiştir. Müfessir memleketinde bir süre görev yapmış, öğrenci yetiştirmiş, eser yazmış, daha sonra hac vazifesi için Suudi Arabistan'a gelmiş, orada tanıştığı hocaların tavsiyesi ve aracılığıyla bu ülkeye yerleşmiş, geri kalan ömrünü burada geçirmiştir. Şinkîtî başta Medine İslam Üniversitesi olmak üzere muhtelif üniversitelerde görev yapmış, özel dersler vermiş, muhtelif eserler yayınlamıştır. Bilhassa bu ülkede etkin olan selefi anlayışı benimsemiş ve bu anlayış üzere kitaplar ve makaleler yazmıştır. 1893/1973 y1lında vefat etmiştir. Şinkîti'nin en önemli eseri Edvâu'l-beyân fî îzâhi'l-Kur'âni bi'lKur'ân adlı eseridir. eş-Şinkîtî, öğrencisi Atiyye Muhammed b. Sâlim'in 1srarlı soruları ve talebi üzerine bu tefsiri yazmaya karar vermiştir. 1954 yılında yazmaya başladığ1 eserini vefat ettiği 1973 yılına kadar sürdürmüştür. Fakat müellif, vefat ettiğinde henüz tefsirini tamamlayamamıştır. Zira Şinkîtî son olarak Mücadele sûresini tefsir etmiştir. Vefatının ardından tefsiri yazmasında büyük emeği olan öğrencisi Atiyye Muhammed, hocasının tavrı ve üslubu üzere ${ }^{36}$ Haşr sûresinin

35 Birışık, Hind Altkıtası Düşünce ve Tefsir Ekolleri, 313-324; Ataöv, "Mevlânâ Âzâd", 72-73; Kardaş, Ebû̀'l-Kelâm Âzâd ve el-Hilâl Gazetesi Çerçevesinde Türkiye ve Türkler, 53; Özcan, “Ebü'l-Kelâm Âzâd”, 10: 335-336; Sel, "Mevalana Ebu'l-Kelam Azad”, 26-28.

36 Bk. Atiyye Muhammed Sâlim, Tetimmetu Edvâi 'l-beyân fì idâhi 'l-Kur'âni bi'l-Kur'ân, 2. Bask1, (y.y., 1400/1980), 8: 3-8. 
başından Nas sûresinin sonuna kadarki kısımları tefsir ederek eseri tamamlamıştır. ${ }^{37}$ Böylece eser 9 cilt haline kâmil bir tefsir olarak neşredilmiştir.

\section{Zehretu't-tefâsîr: Muhammed Ebû Zehre (v. 1394/1974)}

Muhammed Ebû Zehre, Mısır ilim ve kültür camiasının yakından tanıdığı önemli bir isimdir. Küçük yaşlarda başladığı eğitimini Dâru'l-Ulûm'dan mezun olarak tamamlamıştır. Özel dersler ve okumalarla kendini yetiştiren Ebû Zehre, daha sonra muhtelif kurumlarda dersler vererek ilmin gelişmesine katkı sağlamıştır. Ayrıca Ebû Zehre çok sayıda eser yazmıştır. Bunlardan biri de Zehretu't-tefâsîr adlı eseridir. Müellif, zamanının önemli bir kısmını bu eserine tahsis etmiştir. Eserde kullanılan üslup, mevzuların anlatılış tarzı müellifin bu konudaki maharetini göstermektedir. Ancak müellif eserini ikmâl edememiştir. Ebû Zehre, 1370/1951 yılında yazmaya başladığı ve 23 yılını verdiği eserini tamamlayamamış; 12 Nisan1974 yılında Cuma günü tefsirini yazarken rahatsızlanmış, aynı gün vefat etmiştir. Müellif vefat ettiğinde Neml sûresinin (Oysa senin rabbin onların kalplerinde gizlediklerini

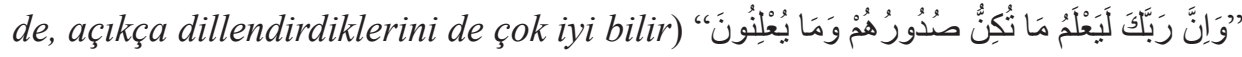
şeklindeki 74. âyetinin tefsirini yazıyordu. ${ }^{38}$ Eserin geri kalan kısımları herhangi biri tarafından ikmâl edilmemiş, 5482 sayfa ve 10 cilt olarak basılmış olan tefsir, ${ }^{39}$ eksik bir tefsir olarak kalmıştır.

37 Bk. Sâlim, Tetimmetu Edvâi'l-Beyân fì İdâhi'l-Kur'âni bi'l-Kur'ân, 8: 9-693, 2: 3-697; Abdurrahman b.Abdulaziz es-Sudeys, Menhecu eş-Şeyh eş-Şinkîtî fî tefsiri âyâti'l-ahkâm min Edvâi'l-beyân, (Yüksek Lisans Tezi, Câmiatu Ummi'l-Kurâ, 1410), 1-22, 126-129; Aişe bint Muhammed Adlan el-Has'amî, Ulûmu'l-Kur'ân inde Muhammed el-Emin eş-Şinkîtî cem'an ve dirâseten, (Yüksek Lisans Tezi, Câmiatu'l-İmam Muhammed b. Suûd el-İslâmiyye, 2007), 16-19; Hâlid b. Osman es-Sebt, "Tercemetu eş-şeyh el-allâme el-müfessir el-usûlî Muhammed el-Emîn eş-Şinkîtî”, Edvâu'l-beyân fì izâhi'l-Kur'âni bi'l-Kur'ân, nşr. Bekir b. Abdillah Ebû Zeyd, (Mekketu'l-Mükerreme: Dâru'l-âlemi'l-fevâid, ts.), 1: 19-39; Erdoğan Baş, "Şinkîtî, Muhammed Emin", DIA , (İstanbul: Türkiye Diyanet Vakfı Yayınları, 2010), 39: 172-173; Muhammed b. Abdurrahman el-Mağrâvî, el-Müfessirûn beyne 't-te'vîl ve'l-isbât fî âyâti 's-sıfât, (Beyrût: Müessestu'r-risâle, 1420/2000), 2: 701; Muhammed b. Sîdî Muhammed Mevlây, et-Tefsir ve'l-müfessirûn bi bilâdi Şinkît risâle ilmiyye tenâvelet el-müfessirîn eş-Şinkîtiyyîn ve tefâsîrihim hilâle mâ yerbû alâ erbaati kurûn, (Moritanya-Kuveyt; Dâru Yûsuf b. Taşfîn-Mektebetu'l-İmâm Mâlik, 1429/2008), 130-134; er-Rûmî, İtticâhâtu 't-Tefsir fi'l-Karni'r-Râbi' Aşer, 2: 522-528.

38 Bk. Muhammed Ebû Zehre, Zehretu't-tefâsîr, (Dâru'l-fikri'l-arabî, ts.), 5482.

39 Saffet Köse, "Muhammed Ebû Zehre", DİA, (İstanbul: Türkiye Diyanet Vakfı Yayınları, 2005), 30: 519-520; Üsretu'l-İmam el-Celil Muhammed Ebû Zehre, “Ta'rîf bi'l-İmam el-Celil Muhammed Ebû Zehre”, Zehretu 't-tefâsîr, (Misır: Dâru'l-fikri'l-arabî, ts.), 1: 3-11; Saffet Köse, "Muhammed Ebû Zehre (1898-1974) Hayat1, İslam Hukuku ve Diğer Disiplinlerle İlgili Bazı Görüşleri-Eserleri”, İslam Hukuku Araştırmaları Dergisi 6 (2005): 480-484; Muhammet Yılmaz, Muhammed Ebû Zehre ve Zehretu't-Tefâsîr İsimli Tefsirindeki Metodu, (Doktora Tezi, Marmara Üniversitesi, 2010), 23-82. 


\section{Kitab tafsir harian al-Quran al-Karim: el-Haz Abdullah Abbas Nasutiyun (v. 1398/1978)}

Malezya'da şöhret bulan el-Haz Abdullah Abbas Nasutiyun (ناسوتيون), 1912 y1lında Kuzey Sumatra'da dünyaya gelmiştir. Müellif ailesiyle birlikte dinî ilimler tahsil etmek üzere Malezya'ya göç etmiştir. Malezya' daki muhtelif eğitim kurumlarında okuyup kendini yetiştiren müellif, hayatı boyunca pek çok alanda faaliyette bulunmuş, muhtelif konularda eserler telif etmiştir. ${ }^{40}$ Bunlardan biri de Kur'ân-1 Kerim'in Çağdaş Tefsiri anlamına gelen Tefsir hâriyan el-Kur'ân el-Kerîm adlı eseridir. Müellif, 1959 yılında bu eserini yazmaya başlamıştır. Eser müellifin daha önce yazmış olduğu al-Quran bergantung makna Jawi untuk bacaan anak sehari-hari adındaki Kur'ân-1 Kerim'in tefsiri tercümesini ikmâl etmek üzere yazılmıştır. Müellif bu eserinden âyeti ve tercüme kısımlarını almış, sonra tefsirini yapmıştır. Eser 2 cilt halinde hazırlanmıştır. Birinci cilt Kur'ân'ın başından A'râf sûresi 27. âyetine kadarki kısımları kapsamaktadır. İkinci cilt ise A'râf 28. âyet ile başlayp Kehf sûresi 87. âyetle sona ermektedir. ${ }^{41}$ Tefsirin geri kalan kısımlarıyla ilgili herhangi bir bilgi tespit edilememiştir. Dolayısıyla bu tefsiri eksik kalmış gibi görünmektedir.

\section{Pertevi ez Kur'ân: Âyetullah Muhammed Alâî Tâlekânî (v. 1399/1979)}

Farsça bir tefsir olan Pertevi ez Kur'ân, Âyetullah Muhammed Alâî Tâlekânî'nin önemli eserlerindendir. Tâlekânî, İran'da yetişmiş önemli bir âlimdir. Müellif, Şah Rıza Pehlevî’nin yönetim sistemine karşı geldiği için o da diğer pek çok İranlı âlim ve mütefekkir gibi hapse atılmış, uzun süre hapiste kalmıştır. Ona göre İran'da ve diğer bölgelerde yaşanan sorunların çaresi Kur'ân'dır, bunlar ancak Kur'ân'ın emirleri uygun olarak yaşandığı zaman halledilir. Müellif eserlerini bu paradigma üzerinden yazmıştır. 1979 yılında İran'daki İslâmî devrimden kısa bir süre önce vefat eden müellifin Pertevi ez Kur'ân adlı tefsiri 6 cilt halinde basılmıştır. Tefsir Nisa sûresi 24. âyetle son bulmuştur. Başka bir ifadeyle Fatiha-Nisa 24. âyet arası 6 cilt halinde tefsir edilmiştir. Geri kalan kısımları yazmaya müellifin ömrü vefa etmemiştir. ${ }^{42}$ Eser daha sonra herhangi biri tarafından tamamlanmamış, eksik bir tefsir olarak kalmıştır.

40 Zülkifli Hac Muhammed Yusuf-E. Mazlan İbrahim, "Tefsir Hâriyan el-Kur'ân el-Kerîm”, Buhûs mu'temeri menâhici tefsiri'l-Kur'âni'l-Kerîm ve şerhi'l-Hadisi'ş-Şerif Malezya: 21-22 Cumadilahire 1427/17-18 Ağustos 2006, (Malezya: University Malaya, 1427/2006), 375-382.

41 Yusuf- İbrahim, “Tefsir Hâriyan el-Kur’ân el-Kerîm”, 382-383.

42 Hidayet Aydar, Tarih Perspektifinden Örnek Tefsir Metinleri 3, (İstanbul: Yeni Zamanlar Yayınları, 2014), 3: 77. 


\section{Tefsîru'l-beyân fi'l-muvâfaka beyne'l-hadîsi ve'l-Kur'ân: Muhammed Hüseyin et-Tabatabâî (v. 1401/1981)}

Muhammed Hüseyin Tabatabâî, İran ilim havzasında yetişmiş en önemli âlimlerden biridir. Küçük yaşlarda başladığı eğitimini İran' da ileri gelen hocalardan ders alarak ve köklü eğitim kurumlarında okuyarak tamamlamıştır. Müellif, dinî ilimler yanında felsefe ve hikmet alanında da yetişmiş ve muhtelif eserleri telif etmiştir. Onu asıl meşhur kılan el-Mîzân adlı tefsiridir. ${ }^{43}$ Müellif oldukça hacimli olan bu eserinden başka bir de hadisler ve Kur'ân arasındaki muvafakati göstermek maksadıyla Tefsîru'l-beyân fí'l-muvâfaka beyne'l-hadîsi ve'l-Kur'ân adıyla da bir tefsir yazmaya başlamıştır. ${ }^{44}$ Ancak ömrü bu tefsiri tamamlamaya yetmemiştir. Müellif Yûsuf sûresinin "Işste biz böylece Yusuf'a Misır'da önemli bir mevki ve iktidar gücü verdik. Nitekim o, ülkenin her yerinde görevini rahatça yapabiliyor, yetkisini kullanabiliyordu. Biz lütuf ve rahmetimizi (iktidar gücünü) dilediğimize veririz. Yine biz işlerini dürüst yapanların hak ettikleri karşıllğ̆ asla zayi etmeyiz"

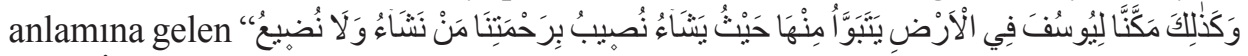

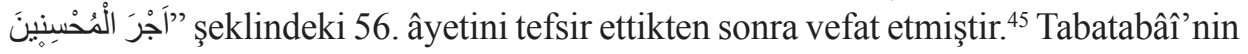
ardından da eserini ikmâl etmek üzere herhangi bir teşebbüste bulunan olmamıştır. Dolayısıyla tefsir tamamlanamamış tefsirlerden biri olmuştur.

\section{Tefsîru'l-Kur'âni'l-Kerîm/Tefsîru'l-Useymîn: Muhammed Salih el-Useymin (v. 1422/2001)}

Suudi Arabistanlı bir âlim olan Muhammed b. Salih el-Useymîn, küçük yaşlarda eğitime başlamış, Abdurrahman $b$. Nasır es-Sa'di gibi âlimlerden dersler almış, ayrıca Muhammed el-Emin eş-Şinkîtî, Abdulaziz b. Bâz gibi hocaların derslerinden yararlanmıştır. Sonra kendisi dersler vermeye başlamış ve öğrenciler yetiştirmiştir. $\mathrm{Bu}$ arada çok sayıda eser telif etmiştir. Bunlardan biri de Tefsiru'l-Useymîn adlı

43 Asğar İrâdetî, "Mukaddimetu't-tahkîk, ta'rif bi'l- müellif”, Tefsîru'l-beyân fi 'l-muvâfakati beyne'l-Hadîsi ve 'l-Kur'ân, thk. Asğar İrâdetî, (Beyrût: Dâru't-teârüf li'l-matbûât, 1426/2006), 1: 21-24; Ali el-Evsî, et-Tabâtabâî ve menhecuhu fî tefsîri'l-Mîzân, (Tahran: Muâviniyyetu'rriâse li'l-alâketi'd-devliyye fî̀ munazzamati'l-a'lâmi'l-İslâmiyye, 1405/1985), 38-56; Kasım el-Hâşimî, "Lemhatun an hayâti'l-müellif", el-Akâid el-İslâmiyye li'l-allâme el-kebîr es-seyyid Muhammed Hüseyin et-Tabâtabâî, nşr. eş-Şeyh Kâsım el-Hâşimî, (Beyrût: Müessesetü'l-a'lemi li'l-matbûât, 1423/2002), 11-13; Seyyid Hüseyin Nasr, "Allame Seyyid Muhammed Hüseyin Tabatabai Kimdir", el-Mizan fi Tefsiri'l-Kur'ân, trc. Vahdettin İnce, (İstanbul: Kevser Yayınları, 1999), 1: 6-11; M. Suat Mertoğlu, "Tabâtabâî, Muhammed Hüseyin”, DİA, (İstanbul: Türkiye Diyanet Vakfi Yayınları, 2010), 39: 306-308.

44 İrâdetî, "Mukaddimetu't-tahkîk, ta'rif bi'l- müellif”, 1: 24-29.

45 Muhammed Hüseyin et-Tabâtabâî, Tefsîru'l-beyân fi'l-muvâfakati beyne 'l-Hadîsi ve 'l-Kur'ân, thk. Asğar İrâdetî, (Beyrût: Dâru't-teârüf li'l-matbûât, 1426/2006), 6: 80-81. 
tefsiridir. ${ }^{46}$ Şeyh Useymin, sohbetlerinde doğrudan Kur'ân'1 okuyarak öğrencilerine tefsir etmiştir. Hicrî 1407 yılında Fâtiha sûresiyle başladığı bu tefsirini vefat ettiği güne kadar sürdürmüştür. 1422 yılında vefat ettiğinde En'âm sûresi 52. âyete ulaşmıştı. Müfessirin yaptığı tefsirler öğrencileri tarafından kayda alınmakta, sonra çözümlenmekte, kendisinin onayına sunulmakta, daha sonra tahkik ve tahrici yapılarak basılmaktaydı. Nitekim Fatiha ve Bakara sûresi öğrencilerinden Halid b. Hamid b. Halil tarafından bu şekilde hazırlanarak basımı gerçekleştirilmiştir. ${ }^{47}$ el-Useymîn, bu şifahi tefsirin geri kalan kısımlarını yapmaya zaman bulamamıştır. Söz konusu eser, onun en büyük ve en kapsamlı tefsiridir. ${ }^{48}$ Başka yerlerde yaptığı sohbetlerdeki tefsirleri de kayda alınıp çözümlenip neşredilmiştir. Sonra bütün bu tefsirler bir araya getirilerek basılmıştır. Tefsir, Kur'ân'ın başından yani Fâtiha sûresinden başlamakta ve Nas sûresiyle bitmektedir. Bununla birlikte En'am'ın sonundan Kehf' in başına kadar yani A'râf-İsrâ arası mevcut değildir. Eserde Kehf suresinin tesirine yer verilmiş, ancak Meryem-Müminûn arasının tefsiri (bu iki sûre de dâhil olmak üzere) yapılmamıştır. Ayrıca Duhân-Fetih arasının tefsiri (bu iki sûre de dâhil olmak üzere) de eserde bulunmamaktadır. Hucurât-Hadîd arası tefsir edilmiş olmasında rağmen fakat 28. cüzden hiçbir sûre yani MücadeleTahrim arasındaki sûreler (bu iki sûre de dâhil olmak üzere) tefsir edilmemiştir. Mülk sûresinden başlamak üzere Nas sûresinin sonuna kadarki kısımların tefsiri mevcuttur. Böylece tefsirin 30 sûreden ibaret olan bazı sûreleri eksik kalmıştır. Geri kalan kısımların tefsiri mevcuttur. Useymin'in vefatının ardından tefsir edilmeyen bu 30 sûreyi onun tarzı ve tavrı üzere tamamlayan olmamıştır. Dolayısıyla eser, eksik tefsirler arasında yerini almıştır.

\section{Meâricu't-tefekkür ve dekâiku't-tedebbür: Abdurrahman Hasan Habenneke el-Meydânî (v. 1425/2004)}

Suriyeli bir âlim olan el-Meydânî, babasından ve dönemin âlimlerinden iyi bir eğitim almıştır. Dönemin Baas rejimi altında ailecek büyük sıkıntılar çekmişlerdir. Müellif önce Lübnan'a, daha sonra da Suudi Arabistan'a yerleşmiş, çok uzun yıllar

46 Ahmed b. Muhammed b. İbrahim el-Berîdî, Cuhûdu'ş-şeyh İbn Useymîn ve ârâuhu fi t'-tefsî̀ ve ulûmi 'l-Kur'ân, (er-Riyâd: Mektebetu'r-rüşd, 1426/2005), 23-54; el-Kısmu'l-ilmî fî müesseseti eşŞeyh Muhammed b. Sâlih el-Useymîn el-hayriyye, "Nebze muhtasara mine'l-allâme Muhammed b. Sâlih el-Useymîn 1347-1421 h.”, Şerhu usûlin fi 't-tefsîr li fadîleti 'ş-şey el-allâme Muhammed b. Sâlih el-Useymîn, (er-Riyâd: Müessesetu'ş-şeyh Muhammed b. Salih el-Useymîn el-hayriyye, 1434), 7-15.

47 el-Lecne el-İlmiyye fî̀ müessesti'ş-Şeyh Muhammed b. Sâlih el-Useymin el-hayriyye, Tefsîru'lKur'âni'l-Kerim el-Fâtiha-el-Bakara li fadîleti'ş-şeyh el-allâme Muhammed b. Sâlih el-Useymîn, (er-Riyâd: Dâru İbnu'l-Cevziyye, ts.), -elif- 
orada hocalık yapmıştır. 2003 yılında akrabalarının ısrarı üzerine Şam'a gelmiş, 9 ay burada kalmış, o arada kanser hastalığ sebebiyle 2004 yılında vefat etmiş ve Şam'da defnedilmiştir. ${ }^{49}$ Meâricu 't-tefekkür adlı tefsiri nüzûl sırasına göre ele alınmış bir tefsirdir. ${ }^{50}$ Eser istiâze ve besmelenin tefsirinin ardından ${ }^{51}$ Alak sûresinin tefsiriyle başlamaktadır. ${ }^{52}$ Müellif, 15 ciltte Mekkî sureleri işlemiştir. Arkasından Bakara sûresine başlamıştır. Ancak geri kalan kısımları yazmaya ömrü vefa etmemiştir. Müellifin vefatından sonra eseri ikmâl etmeye kalkışan olmamıştır. Böylece tefsir müellifi tarafından tamamlanamamış tefsirlerden biri olarak kalmıştır.

Buraya kadar, daha çok öne çıktığını, daha fazla meşhur olduğunu müşahede ettiğimiz tefsirleri verdik. Tespit ettiğimiz tamamlanmamış daha başka tefsirler de vardır. Makalenin sınırlarını aşacağından bunlara yukarıda zikrettiklerimiz gibi yer veremedik. Ancak çalışmayı bütünlemesi açısından bunları burada yukarıdaki listenin devamı olarak, hakkında bilgi vermeden sadece ismen vermeyi uygun gördük.

1 - et-Tefsîr el-mensûb ile'l-İmam Ebî Muhammed el-Hasan b. Ali el-Askerî (v. 260/874)

2 - et-Te'vîlâtu'n-Necmiyye: Necmüddin Kübrâ (v. 618/1222)

3 - Reyyu'z-zam'ân/et-Tefsiru'l-kebîr: Şerefüddin el-Mürsî (v. 655/1257)

4 - Mecmau'l-bahreyn ve metlau'l-bedreyn: Celâlüddin es-Suyûtî (v. 911/1505)

5 - Câmiu'l-envâr ve nüzhetu'l-ebsâr: Tacüddin Tirevî (v. 970/1562)

6 - Tefsîru'l-Kur'ân/Tefsîru'l-Karamanî: Esam el-Karamanî (v. 981/1573)

7 - Tefsîru'l-Birgivî: Takiyuddin el-Birgivî (v. 981/1573)

8 - Menbau uyûni'l-maânî ve matlau şemsi'l-mesânî: Mübarek b. Hidır Nâğurî (v. 1001/1593)

9 - Tefsîru'l-Kur'âni'l-Kerîm: Sadruddin eş-Şîrâzi (v. 1050/1641)

10 - Tefsir-i Şah/Şâh-i tefâsîr: Şah Muhammed b. Abd-i Muhammedî (v. 1072/1662)

49 Necmettin Çalışkan, Abdurrahman Hasan Habenneke el-Meydânîve Tefsiri, (Doktora Tezi, Ankara Üniversitesi, 2013), 17-35; a.mlf., "Nüzûl Sırasına Göre Yeni Bir Tefsir: Abdurrahman Hasan Habenneke el-Meydânî ve Meâricu't-Tefekkür”, Toplum Bilimleri Dergisi $7 / 14$ (2013): 365-367.

50 Çalışkan, Abdurrahman Hasan Habenneke el-Meydânî ve Tefsiri, 95-316; a.mlf., "Nüzûl Sırasına Göre Yeni Bir Tefsir: Abdurrahman Hasan Habenneke el-Meydânî ve Meâricu’t-Tefekkür", 369-371; Esma Abdurrahman Zaeter-Nassâr Es'ad Nassâr, "Davâbitu't-tefsîr inde Andurrahman Hasan Habenneke el-Meydân̂̂”, Mecelletu Câmiati 'ş-Şârika li 'l-ulûmi 'ş-şer 'iyye ve 'l-kânûniyye 14/1 (2017): 213-238.

51 Abdurrahman Hasan Habenneke el-Meydânî, Meâricu 't-tefekkür ve dekâiku 't-tedebbür, (Dimaşk: Dâru'l-kalem, 1420/2000), 1: 9-28. el-Meydânî, Meâricu 't-tefekkür ve dekâiku't-tedebbür, 1: 29-74. 
11 - Tefsiru'l-Kur'ân: Şeyh Nasuhî Mehmet Efendi (v. 1130/1718)

12 - Tefsir-i Refi' 'î: Şah Refiuddin Dihlevî (v. 1233/1818)

13 - Fethu'l-Azîz: Şah Abdulazîz Dihlevî (v. 1239/1824)

14 - Tefsîru Burucerdîlet-Tefsiru'l-kebir/es-Sirâtu'l-müstakim: Hüseyin Bakır Brucerdî (v. 1277/1860)

15 - Tefsîru'l-Kur'ân: Seyyid Ahmed Han (v. 1316/1898)

16 - Envâr-ı Kur'ân: Bereketzâde İsmail Hakkı Efendi (v. 1336/1918)

17 - Safvetü'l-beyân fì tefsiri'l-Kur'ân: Musa Kazım Efendi (v. 1338/1920)

18 - Mûdihu'l-Furkân: Şeyhu'l-Hind Mahmud Hasan Diyobendî (v. 1338/1920)

19 - Tefsir-i âyâti'l-ahkâm min kelâmi Rabbi'l-enâm: Seyyid Ahmed Hasan Dihlevî (v. 1338/1920)

20 - Cevâhiru'l-efkâr ve meâdinu 'l-esrâr/Tefsîru Bedrân: Abdulkadir b. Ahmed Bedrân (v. 1346/1927)

21 - Tefsîru nizâmi'l-Kur'ân ve te 'vîlu'l-Furkâni bi'l-Furkân: Abdulhamid elFerâhî (v. 1348/1930)

22 - Tefsîru Âlâirrahmân: Muhammed Cevad Belaği (v. 1352/1934)

23 - İlhâmu'r-Rahman fì tefsiri 'l-Kur'ân: Ubeydullah Sindî (v. 1363/1944)

24 - Diyâu'l-ekvân fì tefsiri 'l-Kur'ân: Ahmed Saad el-Akkâd (v. 1373/1954)

25 - Tefsîru'l-Hasenât: Ebu'l-Hasenât Muhammed Ahmed Kâdirî (v. 1380/1961)

26 - Tezkire: İnâyetullah Han el-Meşrikî (v. 1382/1963)

27 - Tefsîru'l-Kur 'âni'l-Kerîm: Mahmûd Şeltût (v. 1383/1963)

28 - Tefsîru'l-Furkân fì maârifi'l-Kur 'ân: Hoca Abdulhayy Fârûkî (v. 1384/1965)

29 - Tefsir-i Naîmî/ Eşrefu 't-tefâsîr: Ahmed Yâr Hân Naîmî (v. 1391/1971)

30 - Maârifu'l-Kur'ân: Muhammed İdris Kandehlevî (v. 1394/1974)

31 - Hidâyetü'l-insân fì tefsîri'l-Kur'ân: Ali Ekrem Orbay (1394/1974?)

32 - Safvetu'l-âsâr ve'l-mefâhîm min tefsîri'l-Kur'âni'l-Azîm: Abdurrahman b.

Muhammed ed-Devserî (v. 1399/1979)

33 - Kur'ân-ı Kerim Açılaması (Fatiha ve Bakara Sûreleri): Sadettin Evrin (v. 1401/1981)

34 - Fî rehâbi 'l-Kur 'ân: İbrahim b. Ömer Beyûd (v. 1401/1981)

35 - Tefsîru'ş-Şa'râvî: Muhammed Mütevellî Şa'râvî (v. 1419/1998)

36 - Fethu'r-Rahmâni'r-Rahîm fì tefsiri'l-Kur'âni'l-Kerîm: Muhammed Muhammed Muhammed Sâlim Muhaysin (v. 1422/2001)

37 - et-Tefsir et-tevhîdî: Hasan et-Tûrâbî (v. 2016) 


\section{Sonuç}

Müellifleri tarafindan tamamlanmamış tefsirlerin konu edildiği bu çalışma sonunda tefsir tarihinde müellifi tarafindan yazılmaya başlanmış, fakat tamamlanmamış pek çok tefsir olduğunu tespit ettik. Bunların bir kısmı daha sonra müellifin öğrencisi/ öğrencileri veya çocukları/yakınları tarafından tamamlanmıştır. Bir kısmı ise müelliflerinin ardından ikmâl edilmemiştir. Söz konusu tefsirler farklı zaman, coğrafya, dil ve mezheplerde telif edilmiştir.

Hint Alt kıtasında özellikle son iki asırda bir kısmı müellifi tarafından tamamlanmamış çok sayıda tefsir yazıldığını müşahede ettik. Yine Hind Alt kıtasında eksik tefsirleri tamamlama konusunda daha ciddi gayretlerin olduğunu tespit ettik. Bu vazife, müelliflerin öğrencilerinin yanı sıra çocukları veya daha başka yakınları tarafından yapılmıştır. Buna karşılık Anadolu coğrafyasında yarım kalan tefsirleri tamamlamaya yönelik pek fazla temayülün olmadığı gözlemledik. Oysa bu gelenek, Alâuddin Semerkanî'nin tefsirini tamamlayan Esam el-Karamanî'yle birlikte bu coğrafyada görülmüş, ancak daha sonra sürdürülmemiştir. Geleneğin coğrafyamızda neden devam ettirilmediği hususu, diğer bazı bölgelerdeki durum ile mukayese edilerek özel olarak araştırılabilir ve buna göre bazı tespitler yapılabilir.

Osmanlının son döneminde eksik kalmış bazı tefsirler olmasına rağmen Cumhuriyet döneminde ehil kişiler tarafindan yazılıp eksik kalmış herhangi bir tefsir tespit edemedik. İsmail Cerrahoğlu ve Talat Koçyiğit'in başlangıçta birlikte hazırladıkları ve birinci cildini bastırdıkları, ancak Cerrahoğlu'nun vazgeçmesiyle eksik kalan Kur'an-ı Kerim Meal ve Tefsiri adında bir tefsir vardır. Fakat bu tefsir daha sonra Talat Koçyiğit tarafından tamamlanmış ve 7 cilt olarak basılmıştır.

Araştırmamızdan elde ettiğimiz bulgulara göre eksik kalmış tefsirlerin önemli bir kısmı eser telif etmek için değil, cami, ders halkası ve benzeri ortamlarda yapılan sohbet, vaaz ve irşat faaliyetlerinin neticesinde oluşturulan tefsirlerdir. Bunlar ilerleyen zamanlarda dinleyiciler tarafından kasetlere kaydedilmiş, daha sonra çözümlenerek yazıya geçirilmiş ve basılmıştır.

Tefsirlerin müellifi tarafından tamamlanmamış olmasının en büyük nedeni vefattır. Bunun yanında hapse atılmak, meşguliyet ve imkânsızlık da bazı tefsirlerin eksik kalmasında etkili olmuştur. Eksik tefsirlerimizin bir kısmı esaret, hapis ve gözetim altındayken yazılmışlardır. Savaş başta olmak üzere herhangi bir sebepten yok olan, kaybolan eksik tefsirler de mevcuttur.

$\mathrm{Bu}$ çalışma vesilesiyle daha önceden eksik kaldığ ileri sürülen bazı tefsirlerin tamamlanmış versiyonlarına ulaşılmıştır. Böylelikle literatüre eksik olarak kaydedilen tefsirlerin tamamlanmış tefsirler arasına alınması yönünde bir katkı 
sağlanmıştır. Ancak tamamlanan tefsirlerin bazıları tam olarak yazılmış olmakla birlikte tamamı değil, bazı ciltleri basılmış, bu yüzden eksik zannedilmiştir. $\mathrm{Bu}$ araştırmada eksik kalan tefsirler konu edildiğinden, tamamlandığı tespit edilen tefsirlere yer verilmemiştir.

$\mathrm{Bu}$ araştırma eksik tefsirlerle ilgili çalışmalar açısından bir başlangıç kabul edilebilir. Tabakât, terâcim, fihrist gibi eserlerin kapsamlı ve detaylı incelenmesi suretiyle eksik tefsirlerin tespiti, bunların eksik kalma sebepleri, özellikleri ve son durumları hakkında yapılacak daha geniş çalışmaların tefsir literatürüne müspet bir katkı sağlayacağını ifade etmek mümkündür.

Hakem Değerlendirmesi: Dış bağımsız.

Çıkar Çatışması: Yazar çıkar çatışması bildirmemiştir.

Finansal Destek: Yazar bu çalışma için finansal destek almadığını beyan etmiştir.

Peer-review: Externally peer-reviewed.

Conflict of Interest: The author has no conflict of interest to declare.

Grant Support: The author declared that this study has received no grant support.

\section{Kaynakça/References}

Abay, Muhammed. “Osmanlı Dönemi Dirayet Tefsirleri”. Türkiye Araştırmaları Literatür Dergisi (TALID) 9/18 (2011): 67-137.

Ağırkaya, Güven. Ettafeyyiş'in Himyânu'z-Zâd ilâ Dâri'l-Meâd Adlı Tefsiri ve Harici Yorumları. Doktora Tezi, Erciyes Üniversitesi, 2019.

Akpınar, Ali. “Celâleyn Tefsiri ve Müellifleri”. Cumhuriyet Üniversitesi Illahiyat Fakültesi 2 (1998): 181-198.

Algar, Hamid. “Bahrü'l-Hakâik ve'l-Meân̂̂”. DİA. 4: 515-516. İstanbul: Türkiye Diyanet Vakfi Yayınlar1, 1991.

Altuntaş, Abdurrahman. Celâleyn Tefsiri ve Metodu. Yüksek Lisans Tezi, Ankara Üniversitesi, 2004.

Alvânî, Muhammed Akki. Muhammed b. Yusuf Etfayş ve menhecuhu fi tefsiri 't-teysîr. Yüksek Lisans Tezi, el-Ma'hed el-Vatani li Usûli'd-Din el-Cezâyir, 1411/1990-1991.

Arpa, Enver. "Şeyhülislam Kemal Paşazade ve Tefsir Anlayışı”. X. Kur'ân Sempozyumu Kur'ân ve Eğitim 12-13 Mayıs 2007/Tokat. 195-214. Ankara: Fecir Yayınları, 2008.

Arslan, el-Emîr Şekib - el-Beyân, Emîr. es-Seyyid Reşid Rızâ ev ihâu erbaîne sene. Nşr. Midhat Yûsuf es-Seb'. el-Kâhire: Dâru'l-Fadîle, ts.

Arslan, Şükrü. “Celâleyn Tefsirinin İsnadı ve el-Mahallı’nin Bakara Sûresinden Yaptığı Tefsiri”. Atatürk Üniversitesi İlahiyat Fakültesi Dergisi 10 (1991): 155-172.

Arslan, Şükrü. "Mahallı”. DIA. 27: 326-327. İstanbul: Türkiye Diyanet Vakfı Yayınları, 2003.

Ataöv, Türkkaya. "Mevlânâ Âzâd". Ankara Üniversitesi Siyasal Bilgiler Fakültesi Dergisi 50/1-2 (1995): 69-76. 
Ateş, Süleyman. “Üç Müfessir Bir Tefsir”. Ankara Üniversitesi Illahiyat Fakültesi Dergisi 18 (1970): 85-104.

Aydar, Hidayet. Tarih Perspektifinden Örnek Tefsir Metinleri 3. İstanbul: Yeni Zamanlar Yayınları, 2014.

el-Bağdâdî, İsmail Başa. Hediyyetu'l-ârifìn esmâu'l-müellifîn ve âsâru'l-musannifîn. İstanbul: Matbaatu'l-behiyye, 1951.

Baltacı, Halil. "Necmeddin Dâye'nin Bahru'l-Hakâik Adlı Tefsirinde İbadetlere Dair Bazı İşârî Yorumlar”. Hitit Üniversitesi Illahiyat Fakültesi Dergisi 10/20 (2011/2): 193-210.

Baş, Erdoğan. "Şinkîtî, Muhammed Emin”, DIA, 39: 172-173. İstanbul: Türkiye Diyanet Vakfı Yayınlar1, 2010.

el-Baytâr, Abdurrezzâk. Hilyetu'l-beşer fî târîhi'l-karni's-sâlis aşer. Thk. Muhammed Behcet elBaytâr. Dimaşk: Mecmau'l-luğati'l-arabiyye, 1382/1963.

el-Berîdî, Ahmed b. Muhammed b. İbrahim. Cuhûdu'ş-şeyh İbn Useymîn ve ârâuhu fi t'tefsîr ve ulûmi 'l-Kur'ân. er-Riyâd: Mektebetu'r-rüşd, 1426/2005.

Bilmen, Ömer Nasuhi. Büyük Tefsir Tarihi Tabakâtü 'l-Müfessirîn. İstanbul: Bilmen Yayınları, 1974.

Birışı, Abdülhamit. Hind Altkıtası Düşünce ve Tefsir Ekolleri. İstanbul: İnsan Yayınları, 2012.

Birışı, Abdülhamit - Eren, Cüneyt. "Sıddîk Hasan Han”. DİA. 37: 92-95. İstanbul: Türkiye Diyanet Vakfi Yayınları, 2009.

Bursalı, Mehmed Tahir. Osmanlı Müellifleri. Ankara: Bizim Büro Basımevi, 2009.

Candan, Abdulcelil. "Celâleyn Tefsirine Eleştirel Bir Yaklaşım”. Yüzüncü Yıl Üniversitesi Illahiyat Fakültesi Dergisi 3 (2000): 341-367.

el-Cemel, Süleyman. el-Futûhâtu'l-ilâhiyye bi tavdîhi tefsiri'l-Celâleyn. Misır: el-Matbaatu'l-âmire, 1303.

Çakmaktaş, Nurullah. İbâzî Müfessir Ettafayyiş ve Teysîru't-Tefsir Adlı Eseri. Yüksek Lisans Tezi, Marmara Üniversitesi, 2009.

Çalışkan, Necmettin. Abdurrahman Hasan Habenneke el-Meydânî ve Tefsiri. Doktora Tezi, Ankara Üniversitesi, 2013.

Çalışkan, Necmettin. "Nüzûl Sırasına Göre Yeni Bir Tefsir: Abdurrahman Hasan Habenneke elMeydânî ve Meâricu’t-Tefekkür”. Toplum Bilimleri Dergisi 7/14 (2013): 363-373.

Çelebi, Evliya. Seyahatname (Anadolu, Suriye, Hicaz). İstanbul: Devlet Matbaası 1935.

Çelebî, Mustafa b. Abdullah Hacı Halife Kâtip. Keşfu'z-zunûn an esâmi'l-kutubi ve'l-fünûn. Beyrût: Dâru ihyâi't-turâsi'l-arabî, ts.

ed-Dâvûdî, Şemsuddin b. Muhammed. Tabakâtu'l-müfessirîn. Thk. Lecne mine'l-ulemâ. Beyrût: Dâru'l-kutubi'l-ilmiyye, ts.

Demir, Ziya. XII-XVI Y.Y. Arası Osmanlı Müfessirleri. İstanbul: Ensar Neşriyat, 2007.

Ebû Zehre, Muhammed. Zehretu 't-tefâsîr. Dâru'l-fikri'l-arabî, ts.

el-Ednevî, Ahmed b. Muhammed. Tabakâtu'l-müfessirîn. Thk. Süleyman b. Salih el-Hizî. el-Medîne el-Munevvere: Mektebetu'l-ulûm ve hikem, 1417/1997.

Emin, Ahmed. Zuamâu'l-ıslâh fi 'l-asri'l-hadîs. Beyrût: Dâru'l-kutubi'l-arabî, ts.

el-Ensârî, Abdullah b. İbrahim. “Ta'rîf bi'l-kitâb ve müellifihi”. Fethu'l-beyân fí makâsidi 'l-Kur 'ân. Haz. Abdullah b. İbrahim el-Ensârî. Beyrût: el-Mektebetu'l-asriyye, 1412/1992. 
Erdoğru, M. Akif. "Şeyh Ali Semerkandî Üzerine Yeni Bilgiler”. 60. Yılında İlim ve Fikir Adamı Prof. Dr. Kâzîm Yaşar Kopraman'a Armağan. Haz. E. Semih Yalçın. 321-330. Ankara: Berikan Yayınları, 2003.

el-Evsî, Ali. et-Tabâtabâî ve menhecuhu fî tefsîri'l-Mîzân. Tahran: Muâviniyyetu'r-riâse li'l-alâketi'ddevliyye fî̀ munazzamati'l-a'lâmi'l-İslâmiyye, 1405/1985.

Goldziher, Ignaz. Mezâhibu't-tefsir el-İslâmî. Trc. Abdulhakim en-Neccâr. Mısır: Mektebetu'l-hancî, $1374 / 1955$.

Gökbulut, Süleyman. Necmeddin Kübrâ ve Kübrevilik. Doktora Tezi, Dokuz Eylül Üniversitesi, 2009.

Gördük, Yunus Emre. "Bakara Sûresi Tefsiri Perspektifinden İmam Birgivî’nin Tasavvufa ve İşârî Te'vile Yaklaşımı”. Amasya İlahiyat Dergisi 12 (2019): 37-51.

Görgün, Hilal. “el-Urvetü'l-Vüskâ”. DİA. 42: 186-188. İstanbul: Türkiye Diyanet Vakfi Yayınları, 2012.

el-Has'amî, Aişe bint Muhammed Adlan. Ulûmu'l-Kur'ân inde Muhammed el-Emin eş-Şinkîtî cem 'an ve dirâseten. Yüksek Lisans Tezi, Câmiatu'l-İmam Muhammed b. Suûd el-İslâmiyye, 2007.

el-Hâşimî, Kasım. "Lemhatun an hayâti'l-müellif”. el-Akâid el-İslâmiyye li'l-allâme el-kebîr es-seyyid Muhammed Hüseyin et-Tabâtabâî. Nşr. eş-Şeyh Kâsım el-Hâşimî. Beyrût: Müessesetü’l-a'lemi li'l-matbûât, 1423/2002.

Hizmetli, Sabri. “Ettafeyyiş”. DİA. 11: 500-501. İstanbul: Türkiye Diyanet Vakfı Yayınları, 1995.

İbn Âşûr, Muhammed el-Fâdıl. et-Tefsîr ve ricâluhu. el-Kâhire: Mecmau'l-buhûs el-İslâmiyye, 1390/1970.

İbn Kemal Başa, Şemsuddin Ahmed b. Süleyman er-Rûmî el-Hanefî. Tefsîru İbn Kemal Başa. Thk. Mahir Edib Habbûş. İstanbul: Mektebetu'l-irşâd, 1439/2018.

İlmiyye Salnamesi. Haz. S.A.Karaman-A.N.Galitekin-C.Dadaş. İstanbul: 1998.

İrâdetî, Asğar. "Mukaddimetu't-tahkîk, ta'rif bi'l- müellif”. Tefsîru'l-beyân fi'l-muvâfakati beyne'lHadîsi ve'l-Kur'ân. Thk. Asğar İrâdetî. Beyrût: Dâru't-teârüf li'l-matbûât, 1426/2006.

İşcan, Mehmet Zeki. Muhammed Abduh'un Dinî ve Siyâsî Görüşleri. Doktora Tezi, Atatürk Üniversitesi, 1997.

Kardaş, Zekai. Ebû'l-Kelâm Âzâd ve el-Hilâl Gazetesi Çerçevesinde Türkiye ve Türkler. Doktora Tezi, İstanbul Üniversitesi, 2011.

Kavak, Özgür. Reşid Rıza'nın Fıkıh Düşüncesi Çerçevesindeki Görüşleri. Doktora Tezi, Marmara Üniversitesi, 2009.

Kehhâle, Ömer Rıza. Mu'cemu'l-müellifin. Beyrût: Dâru ihyâi't-turâsi'l-arabî, ts.

Ken'ânî, Muhammed Ahmed. Kurretu'l-ayneyn ala tefsiri'l-Celâleyn. Beyrût: Şeriketu dâri'lbeşâiri'l-İslâmiyye 1918/1997.

Keskioğlu, Osman. "Muhammed Abduh (1266-1323/1849-1905)". Ankara Üniversitesi İlahiyat Fakültesi Dergisi 18 (1970): 109-136.

Kılıç, Mustafa. İbn Kemâl, Hayatı, Tefsir Dair Eserleri ve Tefsirindeki Metodu. Doktora Tezi, Atatürk Üniversitesi, 1981.

K1lıç, Mustafa. “İbn Kemal Paşa (H. 873-949/M. 1468-69-1534)”. Eyüp Sultan Sempozyumu VI. Haz. İrfan Çalışan. 153-157. İstanbul: Eyüp Sultan Belediyesi, 2003.

el-Kısmu'l-ilmî fî̀ müesseseti eş-Şeyh Muhammed b. Sâlih el-Useymîn el-hayriyye. "Nebze muhtasara mine'l-allâme Muhammed b. Sâlih el-Useymîn 1347-1421 h.". Şerhu usûlin fi 't-tefsîr li fadîleti 'şşey el-allâme Muhammed b. Sâlih el-Useymîn. er-Riyâd: Müessesetu'ş-şeyh Muhammed b. Sâlih el-Useymîn el-hayriyye, 1434. 
Konyalı, İbrahim Hakk1. Âbideleri ve Kitâbeleri ile Karaman Tarihi Ermenek ve Mut Âbideleri. İstanbul: Baha Matbaası, 1967.

Köse, Saffet. "Muhammed Ebû Zehre”. DİA. 30: 519-520. İstanbul: Türkiye Diyanet Vakfi Yayınları, 2005.

Köse, Saffet. "Muhammed Ebû Zehre (1898-1974) Hayat1, İslam Hukuku ve Diğer Disiplinlerle İlgili Bazı Görüşleri-Eserleri”. İslam Hukuku Araştırmaları Dergisi 6 (2005): 479-496.

el-Kur'ânu'l-Kerîm bi'r-resmi'l-Osmanî ve bi hâmişihi tefsiru'l-İmameyn el-Celileyn. Haz. Abdulkadir Arnâût. Dimaşk: Dâru İbn Kesir, ts.

Küçükibrahimoğlu, Osman Nuri, “İbn Kemal Paşa”. Diyanet İşleri Başkanlığl Dergisi 11/2 (1972): 115-118.

el-Lecne el-İlmiyye fî̀ müessesti'ş-Şeyh Muhammed b. Sâlih el-Useymin el-hayriyye. Tefsirru'lKur'âni'l-Kerîm el-Fâtiha-el-Bakara li fadîleti'ş̧-şeyh el-allâme Muhammed b. Sâlih el-Useymîn. er-Riyâd: Dâru İbnu'l-Cevziyye, ts.

Ma, Yunus Abdulhayy. Tahkîk ve dirâsetu sûretey el-Fâtiha ve 'l-Bakara min tefsiri İbn Kemâl Başa t. 940. Yüksek Lisans Tezi, el-Câmiatu'l-İslâmiyye bi'l-Medineti'l-Münevvere, 1411.

el-Mağrâvî, Muhammed b. Abdurrahman. el-Müfessirûn beyne't-te'vîl ve'l-isbât fì âyâti s-sıfât. Beyrût: Müessestu'r-risâle, 1420/2000.

Mahmûd, Munî' b. Abdulhalim. Menâhicu'l-müfessirîn. el-Kâhire: Dâru'l-kitâbi'l-Misrî - Beyrût: Dâru'l-kitâbi'l-Lübnânî, 1421/2000.

Mecdi, Mehmet Efendi. Şakâik-i Nu'mâniye ve Zeyilleri Hadâiku'ş-Şakâik. Haz: Abdülkâdir Özcan. İstanbul: Çă̆rı Yayınları, 1998.

Memmedov, Ramiz. Tabersî'nin Mecmau'l-Beyân Tefsirinde Hz. Peygamber'i İkaz Eden Âyetlerin Yorumu. Yüksek Lisans Tezi, Marmara Üniversitesi, 2006.

Mertoğlu, M. Suat. “Tabâtabâî, Muhammed Hüseyin”. DİA. 39: 306-308. İstanbul: Türkiye Diyanet Vakfi Yayınları, 2010.

Mevlây, Muhammed b. Sîdî Muhammed. et-Tefsir ve'l-müfessirûn bi bilâdi Şinkît risâle ilmiyye tenâvelet el-müfessirîn eş-Şinkîtiyyîn ve tefâsîrihim hilâle mâ yerbû alâ erbaati kurûn. MoritanyaKuveyt; Dâru Yûsuf b. Taşfîn-Mektebetu'l-İmâm Mâlik, 1429/2008.

el-Meydânî, Abdurrahman Hasan Habenneke. Meâricu't-tefekkür ve dekâiku't-tedebbür. Dimaşk: Dâru'l-kalem, 1420/2000.

Mollaibrahimoğlu, Süleyman. Yazma Tefsir Literatürü. İstanbul: Damla Yayınları, 2007.

Muhammed, İbrahim Abdulhalim Muhammed. “İbn Kemal Başa ve menhecuhu fi't-tefsîr”. Havilyyetu kulliyyeti'd-dirâsâti'l-İslâmiyye ve'l-arabiyye li'l-benât bi'l-İskenderiyye 6/35 (2019): 117-157.

Mücâhid, Zekî Muhammed. el-A'lâmü'ş-şarkıyye fi 'l-mieti'r-râbia aşere el-hicriyye. Beyrût: Dâru'1ğarbi'l-İslâmî, 1994.

en-Nahvî, Seyyid Muhammed İctiba. "el-Emîr Siddîk Hasan Hân”. Mecelletu sakâfeti'l-Hind elfasliyye 52/2 (2001): 28-39.

Nasr, Seyyid Hüseyin. “Allame Seyyid Muhammed Hüseyin Tabatabai Kimdir”. el-Mizan fi Tefsiri'lKur'ân. Trc. Vahdettin İnce. İstanbul: Kevser Yayınları, 1999.

Nüveyhid, Adil. Mu'cemu'l-müfessirîn min sadri'l-İslâm hatta'l-asri'l-hâdir. Mısır: Müessesetu Nüveyhid es-sakâfiyye, 1409/1988.

Okuyan, Mehmet. "Necmüddin Dâye ve Tasavvufî Tefsiri”. Ondokuz Mayıs Üniversitesi Ilahiyat Fakültesi Dergisi 8 (1996): 109-121. 
Okuyan, Mehmet. "Necmeddîn-i Dâye”. DİA. 32: 496-497. İstanbul: Türkiye Diyanet Vakfi Yayınları, 2006. Olimov, Yunusdjon. Alaeddin es-Semerkandi'nin Bahru'l-Ulum Adlı Tefsiri ve Kaynakları. Doktora Tezi, Ankara Üniversitesi, 2010.

Özcan, Azmi. "Ebü'l-Kelâm Âzâd”. DİA. 10: 335-336. İstanbul: Türkiye Diyanet Vakfi Yayınları, 1994. Özervarl1, M. Sait. "Muhammed Abduh". DİA. 30: 482-487. İstanbul: Türkiye Diyanet Vakfı Yayınlar1, 2005.

Özervarlı, M. Sait. "Reşid Rıza”. DİA. 35: 14-18. İstanbul: Türkiye Diyanet Vakfı Yayınları, 2008.

Rahman, Yusuf. “Envâru’t-Tenzîl ve Esrâru't-Te'vîl'inde Beyzâvî’nin Hermenötiği”. Trc. İbrahim Görener. Erciyes Üniversitesi Ilahiyat Fakültesi Dergisi 11 (2001): 221-228.

Rızâ, Muhammed Reşid. Târîhu'l-Üstâzi'l-İmâm Muhammed eş-Şeyh Abduh ve fîhi tafsîlu sîretihi ve hülâsetu sîreti mûkizi'ş-şarki ve hakîmi'l-İslâmi es-Seyyid Cemâluddin el-Afgânî. el-Kâhire: Dâru'l-fadîle, 1427/2006.

Rıza, Muhammed Reşid. Tefsiru'l-Kur'âni'l-Hakîm. Mısır: Matbaatu'l-menar, ts.

er-Rûmî, Fehd b.Abdurrahman b. Süleyman. Buhûs fî Usûli't-Tefsîr ve Menâhicih. er-Riyâd: Mektebetu't-Tevbe, ts.

er-Rûmî, Fehd b. Abdurrahman b. Süleyman. İtticâhâtu't-tefsîr fi'l-karni'r-râbi' 'aşer. Beyrût: Müessesetur'r-risâle, 1418/1997.

er-Rûmî, Fehd b.Abdurrahman b. Süleyman. Menhecu'l-medresti'l-akliyye el-hadîse fi 't-tefsîr. 2. Bask1. er-Riyâd: Müessesetu'r-risâle, 1403/1983.

Sâlim, Atiyye Muhammed. Tetimmetu edvâi'l-beyân fì idâhi'l-Kur'âni bi'l-Kur'ân. 2. Bask1. y.y., $1400 / 1980$.

Sami, Şemseddin. Kâmusu'l-a 'lâm. İstanbul: Mihran Matbaası, 1311.

es-Sebt, Hâlid b. Osman. "Tercemetu eş-şeyh el-allâme el-müfessir el-usûlî Muhammed el-Emîn eş-Şinkîtî”. Edvâu'l-beyân fì izâhi'l-Kur'âni bi'l-Kur'ân. Nşr. Bekir b. Abdillah Ebû Zeyd. Mekketu'l-Mükerreme: Dâru'l-âlemi'l-fevâid, ts.

Sel, Fatma. “Mevalana Ebu'l-Kelam Azad”. Haksöz 34 (1994): 24-33.

es-Semerkandi, Seyyid Alaeddin Ali b. Yahya. Muhtasar Bahru'l-Ulum Tefsiri (Ilimler Deryasi). Trc. Ali Kara. Ankara: Mutlu Ticaret, 1421.

Sofuoğlu, Mehmet. Tefsire Giriş. İstanbul: Çağrı Yayınları, 1981/1401.

es-Sudeys, Abdurrahman b.Abdulaziz. Menhecu eş-şeyh eş-Şinkîtî fî tefsiri âyâti l'-ahkâm min Edvâi'l-beyân. Yüksek Lisans Tezi, Câmiatu Ummi'l-Kurâ, 1410.

es-Suyûtî, Celaleddin. Husnu'l-muhâdere fî târîhi Misır ve'l-Kâhire. Thk. Muhammed Ebu'l-Fadl İbrahim. Mısır: Dâru ihyâi'l-kutubi'l-arabî, 1387/1967.

et-Tabâtabâî, Muhammed Hüseyin. Tefsîru'l-beyân fi'l-muvâfakati beyne'l-Hadîsi ve'l-Kur'ân. Thk. Asğar İrâdetî. Beyrût: Dâru't-teârüf li'l-matbûât, 1426/2006.

Taşköprüzâde, Ebû'l-Hayr İsâmüddin Ahmed b. Mustafa. eş-Şekâiku'n-nu'mâniyye fî ulemâi'ddevleti'l-Osmâniyye. Beyrût: Dâru'l-tutubi'l-arabî, 1395/1975.

Taşpınar, Halil. "Muhammed Abduh Bibliyografyası Üzerine Bir Deneme". Cumhuriyet Üniversitesi İlahiyat Fakültesi Dergisi 7/2 (Aral1k 2003): 261-289.

Tayfur, Sabğatullah. Siddîk Hasan Han ve Tefsiri Fethu'l-Beyân. Doktora Tezi, Dicle Üniversitesi, 2018.

Troll, Christian W. "Mevlânâ Ebu'l-Kelâm Âzâd (1888-1958): Çoğulcu Bir Ülke ve Dünya İçinde Yaşayıp Algılanan İslam”. Trc. Şaban Ali Düzgün. İslâmî Araştırmalar 7/1 (Kış 1993-94): 23-34. 
Turan, Şerafettin. “Kemalpaşazâde”. DİA. 25: 238-240. İstanbul: Türkiye Diyanet Vakfi Yayınları, 2002.

Uğur, Ahmet. İbn-i Kemal. Ankara: Kültür ve Turizm Bakanlığı Yayınları, 1987.

Ustakurt, Murat. İbn Kemal Paşa 'nın "Tefsiru'l-Fâtiha” Adlı Eseri. Yüksek Lisans Tezi, Marmara Üniversitesi, 2009.

Üsretu'l-İmam el-Celil Muhammed Ebû Zehre. "Ta'rîf bi'l-İmam el-Celil Muhammed Ebû Zehre”. Zehretu't-tefâsîr. Misır: Dâru'l-fikri'l-arabî, ts.

Yazıcı, İshak. "Bahru'1-Ulûm”. DİA. 4: 517-518. İstanbul: Türkiye Diyanet Vakfi Yayınları, 1991.

Yılmaz, Muhammet. Muhammed Ebû Zehre ve Zehretu't-Tefâsîr İsimli Tefsirindeki Metodu. Doktora Tezi, Marmara Üniversitesi, 2010.

Yusuf, Zülkifli Hac Muhammed - İbrahim, E. Mazlan. “Tefsir Hâriyan el-Kur'ân el-Kerîm”. Buhûs mu 'temeri menâhici tefsiri'l-Kur'âni'l-Kerîm ve şerhi'l-Hadisi'ş-Şerif Malezya: 21-22 Cumadilahire 1427/17-18 A ğustos 2006. 375-392. Malezya: University Malaya, 1427/2006.

Zaeter, Esma Abdurrahman - Nassâr, Nassâr Es'ad. "Davâbitu't-tefsîr inde Andurrahman Hasan Habenneke el-Meydân̂̂”. Mecelletu Câmiati 'ş-Şârika li'l-ulûmi'ş-şer'iyye ve'l-kânûniyye 14/1 (2017): 213-238.

ez-Zebîdî, Kâsid Yâsir. "Menhecu'l-Celâleyn fî̀ tefsîri'l-Kur'âni'l-Kerîm”. Adâbu'r-Râfidîn 5 (1974): 125-150.

ez-Zehebî, Muhammed Hüseyin. et-Tefsîr ve'l-müfessirûn. el-Kâhire: Mektebetu vehbe, ts.

ez-Ziriklî, Hayreddin b. Mahmud b. Muhammed Ali b. Faris. el-A'lâm kâmûsu terâcimi eşheri'r-ricâli ve'n-nîsâi mine 'l-arabî ve 'l-musta'rabîn ve 'l-musteşrikîn. Beyrût: Dâru'l-ilim li'l-mellayin, 2002. 
